\title{
Foraminiferal species responses to in situ, experimentally induced anoxia in the Adriatic Sea
}

\author{
D. Langlet ${ }^{1}$, C. Baal ${ }^{2}$, E. Geslin ${ }^{1}$, E. Metzger ${ }^{1}$, M. Zuschin ${ }^{2}$, B. Riedel ${ }^{3}$, N. Risgaard-Petersen ${ }^{4}$, M. Stachowitsch ${ }^{3}$, and \\ F. J. Jorissen ${ }^{1}$ \\ ${ }^{1}$ Université d'Angers, UMR6112 CNRS LPG-BIAF - Bio-Indicateurs Actuels et Fossiles, 2 Boulevard Lavoisier, 49045 \\ Angers Cedex, France \\ ${ }^{2}$ University of Vienna, Department of Palaeontology, Althanstrasse 14, 1090 Vienna, Austria \\ ${ }^{3}$ University of Vienna, Department of Limnology and Oceanography, Althanstrasse 14, 1090 Vienna, Austria \\ ${ }^{4}$ Aarhus University, Center for Geomicrobiology, Department of Bioscience, 8000 Aarhus C, Denmark
}

Correspondence to: D. Langlet (dewi.langlet@univ-angers.fr)

Received: 30 June 2013 - Published in Biogeosciences Discuss.: 19 July 2013

Revised: 10 February 2014 - Accepted: 17 February 2014 - Published: 4 April 2014

\begin{abstract}
Anoxia was successfully induced in four benthic chambers installed at $24 \mathrm{~m}$ depth in the northern Adriatic Sea for periods varying from 9 days to 10 months. During the 10month period, species richness significantly decreased. Although no significant change in Shannon diversity and evenness was observed, the composition of the foraminiferal assemblages changed with time. This change is due to interspecific differences in tolerance to anoxia. Reophax nanus, Textularia agglutinans and Quinqueloculina stelligera all showed a significant decrease with time, strongly suggesting they are sensitive to anoxia. Conversely, Eggerella scabra, Bulimina marginata, Lagenammina atlantica, Hopkinsina pacifica and Bolivina pseudoplicata appeared to be resistant to the experimental conditions. Quinqueloculina seminula was apparently sensitive to anoxia but showed a clear standing stock increase during the first month of the experiment, which we interpret as an opportunistic response to increasing organic matter availability due to the degradation of the dead macrofaunal organisms. None of the anoxia-sensitive species is able to accumulate intracellular nitrates. Nitrate accumulation could be shown for some tested specimens of the dominant anoxia-tolerant species E. scabra and B. marginata. However, tests on the denitrification capacity of these taxa yielded negative results, suggesting that their resistance to long-term anoxia is not due to their ability to denitrify.
\end{abstract}

\section{Introduction}

Over the last decades, bottom-water hypoxia has occurred in an increasing number of coastal areas as a result of humaninduced eutrophication as well as increased stratification, circulation changes and bottom-water temperature increase. In semi-enclosed basins, hypoxia may appear seasonally as a response to combined pelagic productivity and water column stratification. In benthic environments, increased organic matter consumption leads to decreased dissolved oxygen concentration when seasonal water column stratification inhibits oxygen renewal. Seasonal oxygen depletion has been observed in the Adriatic Sea (e.g., Stachowitsch, 1984; Jorissen et al., 1992) with different intensity, varying from hypoxia (defined as $<63 \mu \mathrm{mol} \mathrm{L}-1$; Helly and Levin, 2004) to anoxia (defined as $0 \mu \mathrm{mol} \mathrm{L}{ }^{-1}$; Bernhard and Sen Gupta, 1999; Middelburg and Levin, 2009). The frequency of these low-oxygen events increased from the 1970s to the 1990s, and decreasing again after the 1990 s as a result of reduced continental nutrient inputs (Giani et al., 2012).

Oxygen-depletion events can drastically affect benthic faunas. Macrofaunal organisms $(>1 \mathrm{~mm})$ are apparently more sensitive than meiofaunal organisms $(>45 \mu \mathrm{m}$ and $<1 \mathrm{~mm}$ ) to hypoxic and anoxic conditions (Moodley et al., 1997; Diaz and Rosenberg, 2008). Among meiofauna, copepods are most sensitive, whereas several nematode genera can survive up to 60 days of anoxia (Wieser and Kanwisher, 1961). Benthic foraminifera appear to be most tolerant 
(Moodley et al., 1997) and can survive up to 10 months of anoxia (Bernhard and Reimers, 1991; Langlet et al., 2013). This surprisingly long period may be due to a shift to anaerobic metabolism: some species of the eukaryotic benthic foraminifera can accumulate large quantities of nitrates in their cells and can denitrify during anoxia (Risgaard-Petersen et al., 2006; Høgslund et al., 2008; Piña-Ochoa et al., 2010; Bernhard et al., 2012). Nonetheless, despite their high tolerance to anoxia, foraminiferal density and diversity tend to decrease in low-oxygen environments (Blackwelder et al., 1996; Schumacher et al., 2007; Bouchet et al., 2012). Furthermore, not all foraminiferal taxa respond similarly. For instance, in the Adriatic Sea some taxa (Nouria polymorphoides, Reophax nanus and Textularia spp.) appear to be sensitive to hypoxia/anoxia, whereas others (Nonionella turgida, Bolivina spp., Eggerella spp., Bulimina spp., Hopkinsina pacifica and Stainforthia fusiformis) are more tolerant (Jorissen et al., 1992; Moodley et al., 1998; Duijnstee et al., 2004; Ernst et al., 2005; Pucci et al., 2009). Note, however, that these valuable earlier results should be interpreted with caution because they are based on inventories of rosebengal-stained faunas. Rose bengal is a bulk stain that adheres to proteins in the protoplasm (Walton, 1952; Bernhard, 2000). Since foraminiferal protoplasm may remain present after death of the organism, rose bengal can stain a nonnegligible number of dead organisms (Boltovskoy and Lena, 1970; Bernhard, 1988; Hannah and Rogerson, 1997; Murray and Bowser, 2000). The amount of false positives could be even more important in anoxic and hypoxic conditions due to the slow degradation of organic matter there (Burdige, 2006; Glud, 2008). To avoid such artifacts we used CellTracker ${ }^{\mathrm{TM}}$ Green (CTG) to recognize living individuals. CTG is a nonfluorescent probe that passes through the cellular membrane into the cytoplasm, where hydrolysis with nonspecific esterase produces a fluorescent compound (Bernhard et al., 2006). Consequently, fluorescent specimens were enzymatically active when sampled. This approach enabled us to accurately determine live individuals in our experimentally induced anoxia, and to distinguish between species more tolerant or more sensitive to anoxia.

The present study focuses on the northeastern Adriatic Sea, specifically the Gulf of Trieste, which is a recognized area for seasonal hypoxic/anoxic events and is also listed among the "spreading dead zones around the world" (Diaz and Rosenberg, 2008). To control the environmental conditions as best as possible, we adopted an in situ approach and experimentally generated anoxia by placing benthic chambers on the sea floor. The foraminiferal analyses reported in this study and in Langlet et al. (2013) are complemented by geochemical analyses, demonstrating the changes of redox conditions during the experiment (Koron et al., 2013; Metzger et al., 2013). Studies of macrofaunal behavior (Riedel et al., 2008, 2012, 2013; Blasnig et al., 2013) and of copepod and nematode assemblages (De Troch et al., 2013; Grego et al., 2014) show the impact of the experimentally in- duced anoxia on other biota. In the previous companion paper (Langlet et al., 2013), the effect of anoxia on the total foraminiferal standing stocks was determined. Benthic foraminifera were alive at all sampling times, proving that foraminifera can survive up to 10 months of anoxia with cooccurring hydrogen sulfides. In the present study, we focus on the effects of long-term anoxia on individual species and on biodiversity. We determine how the density of the major species changes in response to anoxia, and distinguish between more or less resistant taxa. This approach will allow us to better understand the ecology of key species in foraminiferal communities. It will also provide information that may help us to select species for future laboratory experiments in hypoxic/anoxic conditions, for instance to develop proxies of paleo-oxygenation. Finally, we investigate whether survival of tolerant species can be explained by a shift to anaerobic metabolism (denitrification).

\section{Material and methods}

\subsection{Study area}

Two sites were sampled for the present study: a site in the Gulf of Trieste, where the incubation experiment was conducted, and a second site in the NW Adriatic Sea, where we collected living foraminifera for laboratory analyses. The field experiment was conducted in the Gulf of Trieste (northern Adriatic Sea) near the oceanographic buoy of the Marine Biology Station Piran $\left(45^{\circ} 32.90^{\prime} \mathrm{N}, 13^{\circ} 33.00^{\prime} \mathrm{E}\right)$ at $24 \mathrm{~m}$ depth, on a poorly sorted sandy-silty bottom. This study site was chosen because of the presence of the oceanographic buoy, which allowed for mooring the boat from which the scuba divers operated. The buoy also helped to protect the scientific equipment left on the sea floor for the long-term experiment (up to 10 months), as commercial fishing activity (such as bottom trawling and dredging) is forbidden around the buoy. In late summer, at this site, both the vertical density gradient and marine snow production can result in bottomwater hypoxia or anoxia (Faganeli et al., 1985; Malej and Malacic, 1995).

The experimental setup was adapted from an earlier experiment (Stachowitsch et al., 2007; Riedel et al., 2008) and is described in Langlet et al. (2013). In the field, we used used four different chambers to produce anoxia for different periods of time (Table 1): the Experimental Anoxia Generating Unit (EAGU), which is a $0.125 \mathrm{~m}^{3}$ fully equipped (datalogger and sensor equipment, time-lapse camera) benthic chamber that allows for small-scale anoxia to experimentally induced and documented (Stachowitsch et al., 2007) and features three simple, equally dimensioned Plexiglass ${ }^{\mathrm{TM}}$ chambers.

The four chambers were installed on the sea floor, several meters apart, on substrates that were visually poor in macrofauna. At the beginning of each experiment, two to 
Table 1. Deployment and sampling dates as well as duration of the experimental period for the cores representing in situ conditions ("Normoxia") and the various periods of anoxia in the four different benthic chambers.

\begin{tabular}{llll}
\hline $\begin{array}{l}\text { Sample } \\
\text { ID }\end{array}$ & $\begin{array}{l}\text { Chamber } \\
\text { deployment } \\
\text { day }\end{array}$ & $\begin{array}{l}\text { Core } \\
\text { sampling } \\
\text { day }\end{array}$ & $\begin{array}{l}\text { Incubation } \\
\text { duration }\end{array}$ \\
\hline Normoxia & - & 03.08 .2010 & 0 days \\
9 days & 02.08 .2010 & 11.08 .2010 & 9 days \\
1 month & 27.07 .2010 & 25.08 .2010 & 29 days \\
2 months & 27.07 .2010 & 23.09 .2010 & 58 days \\
10 months & 24.09 .2010 & 05.08 .2011 & 315 days \\
\hline
\end{tabular}

three brittle stars (Ophiothrix quinquemaculata), which are very sensitive to oxygen, were introduced into each chamber to provide rapid, visible indication of the onset of anoxia in each chamber. Two reference cores (termed "normoxia") were sampled at the start of the experiment. In order to standardize the terminology for all articles of the present Biogeosciences special issue, the successive sampling times have been termed " 9 days", "1 month", " 2 months" and "10 months". The exact duration (in days) of each of the experiments is given in Table 1 . The first chamber was fully equipped with analytical devices, documenting the onset of anoxia. The other three chambers, without oxygen sensors, were used to study the development of meiofauna after $\sim 1$ month, $\sim 2$ months and $\sim 10$ months of anoxia, respectively. Foraminifera, copepods and nematodes were analyzed for the same cores. Sediment cores were taken by scuba divers using a Plexiglas corer with a $4.6 \mathrm{~cm}$ inner diameter $\left(16.6 \mathrm{~cm}^{2}\right.$ surface area). Two replicate cores were taken in each of the benthic chambers at each sampling time.

Reliably measuring intracellular nitrate and denitrification requires a large number of fresh and living individuals. The sediment from the Piran station is sandy and rich in dead foraminifera. It was extremely time consuming to find even a few living individuals. Therefore, in September 2012, sediment samples were collected with a Van Veen grab at $12 \mathrm{~m}$ depth at Portonovo Bay station D10 $\left(43^{\circ} 35.5^{\prime} \mathrm{N}, 13^{\circ} 34.9^{\prime} \mathrm{E}\right)$, close to the site studied by Sabbatini et al. (2012), which is slightly finer grained and richer in living foraminifers. Samples were kept in plastic bottles in well-oxygenated sea water (the lid of the bottles partly open) at in situ salinity and temperature $\left(S=35\right.$ and $T=22^{\circ} \mathrm{C}$ ) until further analysis.

\subsection{Faunal analysis}

The methodology of the faunal analyses is described in detail in Langlet et al. (2013). Sediment cores of $4.6 \mathrm{~cm}$ inner diameter were sliced at seven depth intervals, every $0.5 \mathrm{~cm}$ between 0 and $2 \mathrm{~cm}$ and every $1 \mathrm{~cm}$ from 2 down to $5 \mathrm{~cm}$. Each sediment slice was mixed with sea water, to which a CTG-DMSO (CellTracker ${ }^{\mathrm{TM}}$ Green CMFDA (5-chloromethylfluorescein diacetate) - Molecular Probes ${ }^{\circledR}$, Life Technologies ${ }^{\mathrm{TM}}$ - and dimethyl sulfoxide) solution was added, with a final CTG concentration of $1 \mu \mathrm{mol} \mathrm{L}^{-1}$ (Bernhard et al., 2006; Pucci et al., 2009) . Next, the samples were kept in the dark at in situ temperature for at least $10 \mathrm{~h}$, during which the originally nonfluorescent CTG molecule is hydrolyzed by the living individuals and transformed into a molecule that fluoresces when excited at a specific wavelength. In order to perform the faunal analysis at a later stage, the samples were fixed in $4 \%$ formaldehyde buffered with sodium tetraborate.

A specific aspect of this project is that soft-shelled (nematodes, copepods) and hard-shelled meiofaunal organisms (foraminifera) were studied in the same samples (De Troch et al., 2013; Langlet et al., 2013; Grego et al., 2014). In order to separate these two groups of organisms, a density separation was performed by adding a Levasil solution to the sample and centrifuging it at $3000 \mathrm{rpm}$ for $10 \mathrm{~min}$ (McIntyre and Warwick, 1984; Burgess, 2001). Next, the residue containing the sediment and the denser organisms (i.e., the hard-shelled foraminifera) was washed and sieved at different mesh sizes $(63,125,150,315$ and $500 \mu \mathrm{m})$. Thus, softshelled foraminifera that are likely to be found in the supernatant after centrifugation are not considered in the present study. Samples were kept in a sodium tetraborate-buffered formalin solution until further analysis.

Foraminifera from the $63-125 \mu \mathrm{m}$ size fraction were separated from the sediment by the tetrachloride density separation method (e.g., Hohenegger et al., 1989; Murray, 2006) as described by Langlet et al. (2013). No density separation was performed for the size fractions larger than $125 \mu \mathrm{m}$. Samples from all fractions were analyzed under an epifluorescence stereomicroscope (Olympus SZX12 with a fluorescent-light source Olympus URFL-T or Nikon SMZ 1500 with a PRIOR Lumen 200), and only clearly fluorescent individuals were considered to be living.

\subsection{Statistical analysis}

After identifying all living individuals, they were sorted into different taxa, counted (Supplement 6 and 7) and expressed as standing stock (number of living individuals in the $0-5 \mathrm{~cm}$ depth interval normalized for a $10 \mathrm{~cm}^{2}$ surface area), density (number of living individuals per depth interval normalized for a $10 \mathrm{~cm}^{3}$ sediment volume) and relative frequency (percentage of a species with respect to the total fauna). Next, species richness, the Shannon index and evenness were calculated (e.g., Hayek and Buzas, 1997).

Three different procedures were used to estimate the effect of the different parameters on the foraminiferal standing stocks and diversity indices. We systematically used linear models (Chambers and Hastie, 1992) in which the dependent (response) variable must follow a normal distribution. The statistical analyses were performed with $\mathrm{R}$ version 2.14 (R Development Core Team, 2011). In order to obtain a 
Table 2. Name and number of the linear models. For each model type the different dependent and independent variables are listed and the transformation used is presented in brackets. As the models are executed on different data, the categories of the selection are presented.

\begin{tabular}{|c|c|c|c|}
\hline $\begin{array}{l}\text { Model } \\
\text { types }\end{array}$ & $\begin{array}{l}\text { Dependent variable } \\
\text { (transformation) }\end{array}$ & $\begin{array}{l}\text { Independent variable } \\
\text { (transformation) }\end{array}$ & Data selection \\
\hline Model-type $1(\times 8)$ & $\begin{array}{l}\text { Standing stock }(\log ) \\
\text { Species richness } \\
\text { Shannon index } \\
\text { Evenness }\end{array}$ & $\begin{array}{l}\text { Time }(\log ) \\
\text { Time }^{2}(\log )\end{array}$ & Size $(>125 \mu \mathrm{m}$ and $>63 \mu \mathrm{m})$ \\
\hline Model-type $2(\times 18)$ & $\begin{array}{l}\text { Standing stock (log) } \\
\text { Frequency }(\arcsin )\end{array}$ & $\begin{array}{l}\text { Time }(\log ) \\
\text { Time }^{2}(\log ) \\
\text { Depth }(0-0.5 \mathrm{~cm} \text { and } 0-5 \mathrm{~cm}) \\
\text { Time } \times \text { depth } \\
\text { Time }^{2} \times \text { depth }\end{array}$ & $\begin{array}{l}\text { Species (R. nanus, E. scabra, } \\
\text { B. marginata, T. agglutinans, } \\
Q . \text { seminula, L. atlantica, } \\
\text { H. pacifica, B. pseudoplicata } \\
\text { and } Q . \text { stelligera) }\end{array}$ \\
\hline Model-type $3(\times 6)$ & $\begin{array}{l}\text { Standing stock }(\log ) \\
\text { Frequency }(\arcsin )\end{array}$ & $\begin{array}{l}\text { Time }(\log ) \\
\text { Time }^{2}(\log )\end{array}$ & Response types (A, B, C) \\
\hline
\end{tabular}

normal distribution, data transformation was sometimes necessary. In these cases, we applied a log transformation for standing stocks and density, and an arcsin transformation for relative frequencies. Each of our three groups of models, which consider one to four dependent variables, is applied on different data sets (see column "Data selection" in Table 2). In all models the number of independent variables is reduced by backward selection (i.e., variables having a significant effect on the dependent variable are progressively removed) to retain only the variables with a significant effect on the dependent variable. We could expect that the different tested variables did not necessarily show a gradual variation with the sampling time. Therefore the time variable was logtransformed. We also tested the effect of the square of the time in order to examine possible polynomial changes with time.

The first group of models tests the effect of time and time ${ }^{2}$ on standing stock, species richness, Shannon index and evenness in two different samples categories (the $>125 \mu \mathrm{m}$ or $>63 \mu \mathrm{m}$ size fractions in the whole core).

The second group of models is designed to identify whether time, time ${ }^{2}$, depth and their interactions significantly affect the standing stocks and relative frequencies of the major species ( $>4 \%$ in at least one core).

Finally, the third group of models tests the effect of time and depth and their interaction on the total standing stocks and the cumulative relative frequencies of three types of species, which have been selected as a function of the results of the second group of models. Tables 3, 4 and 9 show only those dependent variables with a significant effect, whereas Table 5 and Supplement 4 and 5 show how each variable affects the dependent variables.

\subsection{Nitrate content and denitrification measurements}

The samples for living foraminifera, used in the denitrification experiments, were selected from well-oxygenated substrates (not from anoxic benthic chambers) from both study areas (Piran and station D10; see Sect. 2.1). These samples were kept under oxygenated conditions at all times. Foraminifera were put on a thin layer of sediment $(<38 \mu \mathrm{m})$, and living individuals that moved on the sediment film were picked and washed at least three times with a brush in nitratefree artificial sea water before being put into a $1 \mathrm{~mL}$ centrifugation tube. Samples were kept at $-20^{\circ} \mathrm{C}$ until further analysis. The intracellular nitrate content of single specimens was measured using the $\mathrm{VCl}_{3}$ reduction method and detected by chemiluminescence as described previously (RisgaardPetersen et al., 2006; Høgslund et al., 2008). For the present study a total number of 33 individuals were measured for 7 different species.

For denitrification measurements a maximum number of seven living specimens were placed in an anoxic tube of $0.5 \mathrm{~mm}$ inner diameter containing nitrate-free sea water. $\mathrm{Ni}$ trate respiration rates were then determined from $\mathrm{N}_{2} \mathrm{O}$ profiles measured with a $\mathrm{N}_{2} \mathrm{O}$ micro sensors (Andersen et al., 2001) after acetylene inhibition of $\mathrm{N}_{2} \mathrm{O}$ reduction (Smith et al., 1978; Risgaard-Petersen et al., 2006; Høgslund et al., 2008). In all, five experiments were performed. Note that two of these experiments are pseudoreplicates because three to four individuals from the first set of measurements were reused in the second experiment after introducing further individuals into the measurement chamber. 


\section{Results}

\subsection{Effect of anoxia on standing stocks and diversity}

In the previous companion paper (Langlet et al., 2013), we showed that foraminifera are alive at all sampling times in fairly large numbers (Fig. 1). In the $>63 \mu \mathrm{m}$ fraction, total standing stocks in the whole cores $(0-5 \mathrm{~cm})$ varied between $\sim 1980$ individuals per $10 \mathrm{~cm}^{2}$ at the beginning of the experiment and $\sim 530$ individuals per $10 \mathrm{~cm}^{2}$ at the end. In the whole cores we observed a significant decrease with time in the $>63 \mu \mathrm{m}$ fraction but not in the $>125 \mu \mathrm{m}$ size fraction (Fig. 1, Table 3 and Supplement 5). According to the data presented in the present paper, species richness also tended to decrease with time (Fig. 1). While 74 species were found in total, not all of them were present in all cores. A maximum of 64 species was observed in the $>63 \mu \mathrm{m}$ fraction of one of the "normoxia" cores $(0-5 \mathrm{~cm})$. Minimal values (50 species) were found in the "10 months" cores (Fig. 1). Species richness significantly decreased with time in both the $>63 \mu \mathrm{m}$ and $>125 \mu \mathrm{m}$ size fractions (Table 3 and Supplement 5).

Both other diversity indicators (Shannon index and evenness) showed important differences between the $>63 \mu \mathrm{m}$ and $>125 \mu \mathrm{m}$ size fractions (Fig. 1). In the $>63 \mu \mathrm{m}$ fraction of the whole cores $(0-5 \mathrm{~cm})$, the Shannon index attained a maximum of 2.8 in one of the "normoxia" cores. Evenness varied (from 0.44 to 0.71 ) in the two size fractions. Both the Shannon index and the evenness significantly decreased with time in the $>125 \mu \mathrm{m}$ fraction, but not in the $>63 \mu \mathrm{m}$ fraction (Fig. 1, Table 3 and Supplement 5).

\subsection{Species response to the experimental conditions}

Here, we considered the nine major species ( $\geq 4 \%$ in one of the cores). The effect of time, time ${ }^{2}$ and depth on their standing stocks and relative frequencies was tested by backward variable selection in order to retain only the independent variables that significantly affect the dependent variable. The analysis of variance is presented in Table 4, and the estimation of the coefficients associated with the independent variables in Table 5.

Figure 2 and Supplement 1 showed the absolute densities and relative frequencies of the nine species in the whole cores $(0-5 \mathrm{~cm})$. Reophax nanus, Quinqueloculina seminula, Hopkinsina pacifica, Bolivina pseudoplicata and Quinqueloculina stelligera were largely restricted to the 63-125 $\mu \mathrm{m}$ fraction, whereas Bulimina marginata was mainly found in size fractions below $150 \mu \mathrm{m}$ (Fig. 2). Eggerella scabra and Textularia agglutinans occurred in all size fractions below $315 \mu \mathrm{m}$, whereas Lagenammina atlantica was present almost exclusively in the $>125 \mu \mathrm{m}$ fraction (Fig. 2).

The standing stock of $R$. nanus varied from $\sim 780$ individuals per $10 \mathrm{~cm}^{2}$ in one of the two "normoxic" cores to $\sim 90$ individuals per $10 \mathrm{~cm}^{2}$ in the "10 months" cores (Fig. 2). The standing stocks significantly decreased with time (Fig. 3 and

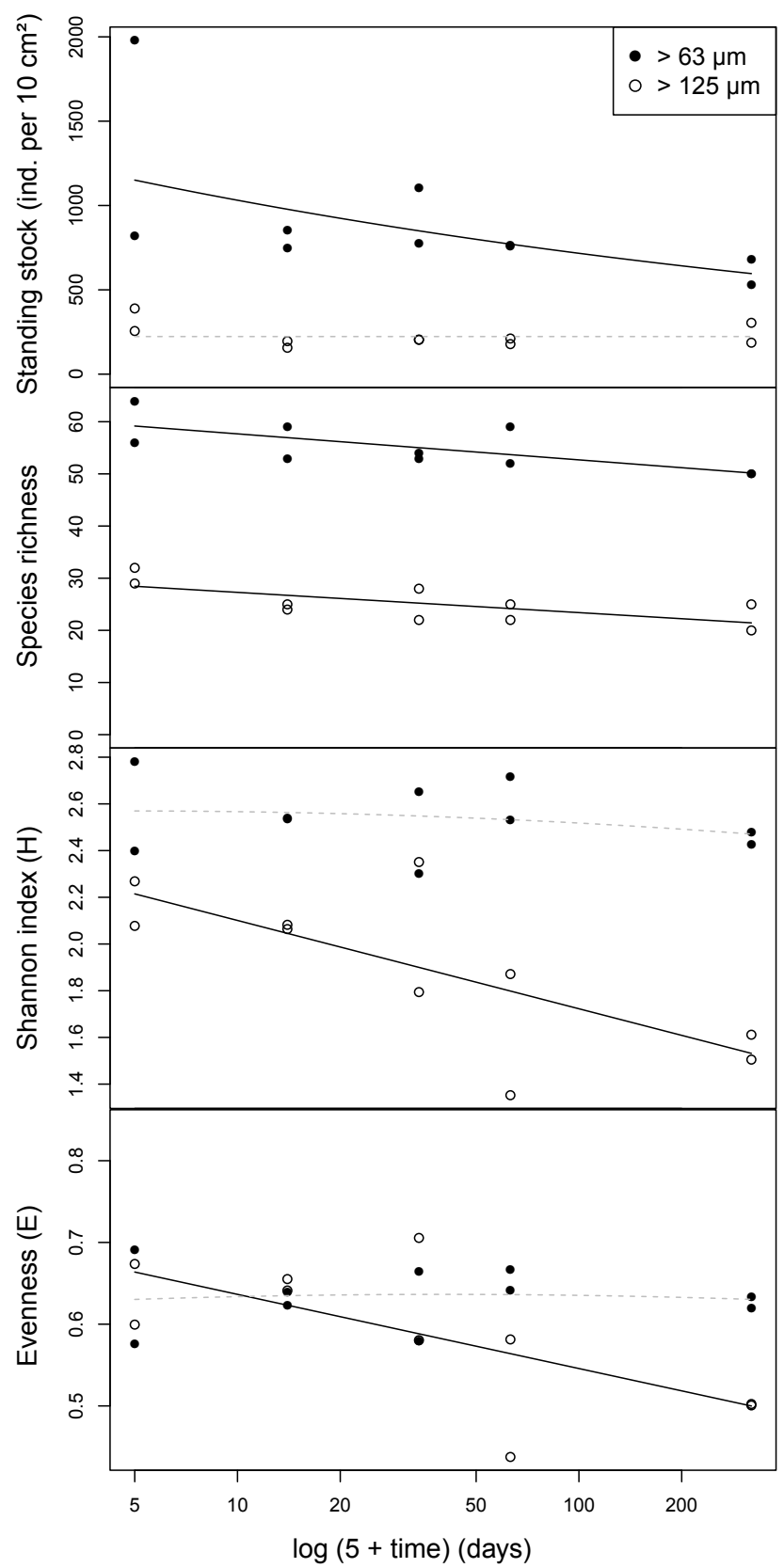

Fig. 1. Standing stock, species richness, Shannon index and evenness variations with time in two size fractions (full circles: $>63 \mu \mathrm{m}$; open circles: $>125 \mu \mathrm{m}$ ). The lines are estimated after the modeltype 1 ; full black line indicates that for the considered size the relationship between the dependent variable and the independent variable is significant, while grey dashed lines indicate no significant relationship.

Table 4), although a slight increase was observed in one of the "1 month" cores. Also, for E. scabra the highest standing stocks were recorded in one of the "normoxic" cores $(\sim 330$ individuals per $10 \mathrm{~cm}^{2}$ ), whereas the lowest standing stocks occurred in the "9 days" and "1 month" samples (110 to 
Table 3. Statistical parameters (Df: degrees of freedom; Sum Sq: sum of squares; Mean Sq: mean of squares; $F$ value: value of the $F$ test; Pr $(>F)$ : probability of the $F$ test) for the model-type 1 at all sampled size fractions and Depth intervals for the four tested dependent variables. For the cases where no significant effect of either the time or time ${ }^{2}$ was observed, only the "residuals" parameters are estimated.

\begin{tabular}{|c|c|c|c|c|c|c|c|}
\hline $\begin{array}{l}\text { Dependent } \\
\text { variable }\end{array}$ & Size & $\begin{array}{l}\text { Independent } \\
\text { variable }\end{array}$ & Df & $\begin{array}{r}\text { Sum } \\
\text { Sq }\end{array}$ & $\begin{array}{r}\text { Mean } \\
\text { Sq }\end{array}$ & $\begin{array}{r}F \\
\text { value }\end{array}$ & $\begin{array}{r}\operatorname{Pr} \\
(>F)\end{array}$ \\
\hline $\begin{array}{l}\text { Standing } \\
\text { stock }\end{array}$ & $\begin{array}{l}>63 \mu \mathrm{m} \\
>125 \mu \mathrm{m}\end{array}$ & $\begin{array}{l}\log (5+\text { time }) \\
\text { residuals } \\
\text { residuals }\end{array}$ & $\begin{array}{l}1 \\
8 \\
9\end{array}$ & $\begin{array}{l}0.5 \\
0.6 \\
0.7\end{array}$ & $\begin{array}{l}0.5 \\
0.1 \\
0.1\end{array}$ & $\begin{array}{l}6.6 \\
\text { NA } \\
\text { NA }\end{array}$ & $\begin{array}{r}0.03 \\
\text { NA } \\
\text { NA }\end{array}$ \\
\hline $\begin{array}{l}\text { Species } \\
\text { richness }\end{array}$ & $\begin{array}{l}>63 \mu \mathrm{m} \\
>125 \mu \mathrm{m}\end{array}$ & $\begin{array}{l}\log (5+\text { time }) \\
\text { residuals } \\
\log (5+\text { time }) \\
\text { residuals }\end{array}$ & $\begin{array}{l}1 \\
8 \\
1 \\
8\end{array}$ & $\begin{array}{l}92.6 \\
89.4 \\
56.1 \\
61.5\end{array}$ & $\begin{array}{r}92.6 \\
11.2 \\
56.1 \\
7.7\end{array}$ & $\begin{array}{r}8.3 \\
\text { NA } \\
7.3 \\
\text { NA }\end{array}$ & $\begin{array}{r}0.02 \\
\text { NA } \\
0.03 \\
\text { NA }\end{array}$ \\
\hline $\begin{array}{l}\text { Shannon } \\
\text { index }\end{array}$ & $\begin{array}{l}>63 \mu \mathrm{m} \\
>125 \mu \mathrm{m}\end{array}$ & $\begin{array}{l}\text { residuals } \\
\log (5+\text { time }) \\
\text { residuals }\end{array}$ & $\begin{array}{l}9 \\
1 \\
8\end{array}$ & $\begin{array}{l}0.2 \\
0.5 \\
0.4\end{array}$ & $\begin{array}{l}0.0 \\
0.5 \\
0.1\end{array}$ & $\begin{array}{r}\mathrm{NA} \\
9.5 \\
\mathrm{NA}\end{array}$ & $\begin{array}{r}\mathrm{NA} \\
0.02 \\
\mathrm{NA}\end{array}$ \\
\hline Evenness & $\begin{array}{l}>63 \mu \mathrm{m} \\
>125 \mu \mathrm{m}\end{array}$ & $\begin{array}{l}\text { residuals } \\
\log (5+\text { time }) \\
\text { residuals }\end{array}$ & $\begin{array}{l}9 \\
1 \\
8\end{array}$ & $\begin{array}{l}0.0 \\
0.0 \\
0.0\end{array}$ & $\begin{array}{l}0.0 \\
0.0 \\
0.0\end{array}$ & $\begin{array}{r}\text { NA } \\
6.9 \\
\text { NA }\end{array}$ & $\begin{array}{r}\mathrm{NA} \\
0.03 \\
\mathrm{NA}\end{array}$ \\
\hline
\end{tabular}
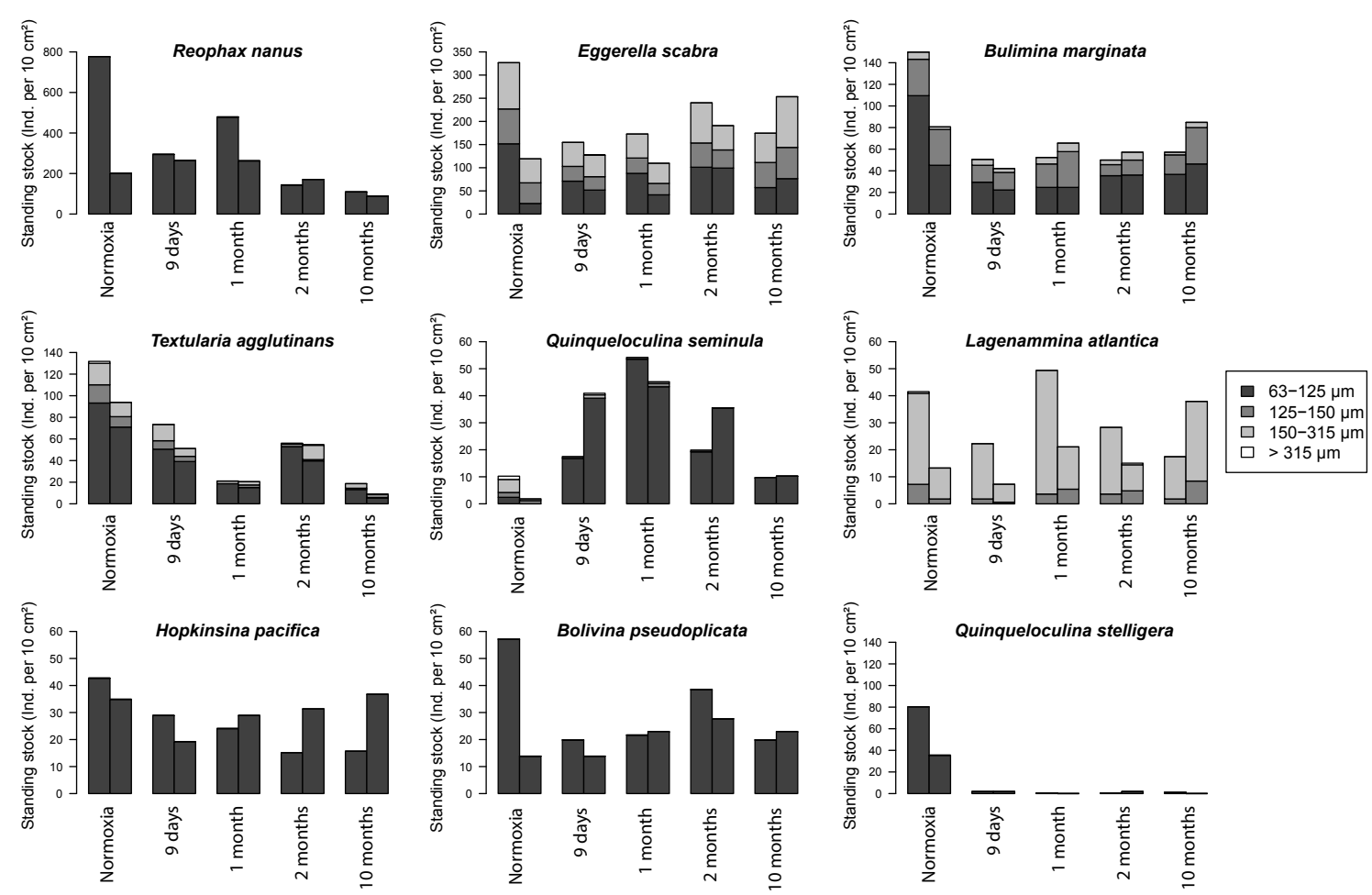

Fig. 2. Standing stock of the nine major species in all the sampled cores (two replicate cores each time) in all studied size fractions in the whole core $(0-5 \mathrm{~cm})$. Note the different vertical scales for the various species.

170 individuals per $10 \mathrm{~cm}^{2}$ ). The standing stock increased slightly after 1 month (Fig. 2), but this trend was not significant (no significant effect of the time ${ }^{2}$ parameter, Table 4).

Very similarly, for $B$. marginata the highest standing stock was also observed in one of the "normoxic" cores $(\sim 150$ individuals per $10 \mathrm{~cm}^{2}$ ), the lowest values in the "9 days" sam- ples $\left(\sim 50\right.$ individuals per $10 \mathrm{~cm}^{2}$, Fig. 2$)$. For this species, the standing stock apparently also decreased in the first week, remaining stable thereafter until the end of the experiment. There was, however, no significant change with time (Fig. 3 and Table 4). Textularia agglutinans showed a significant decrease in standing stock with time, from 130 to 90 individuals 

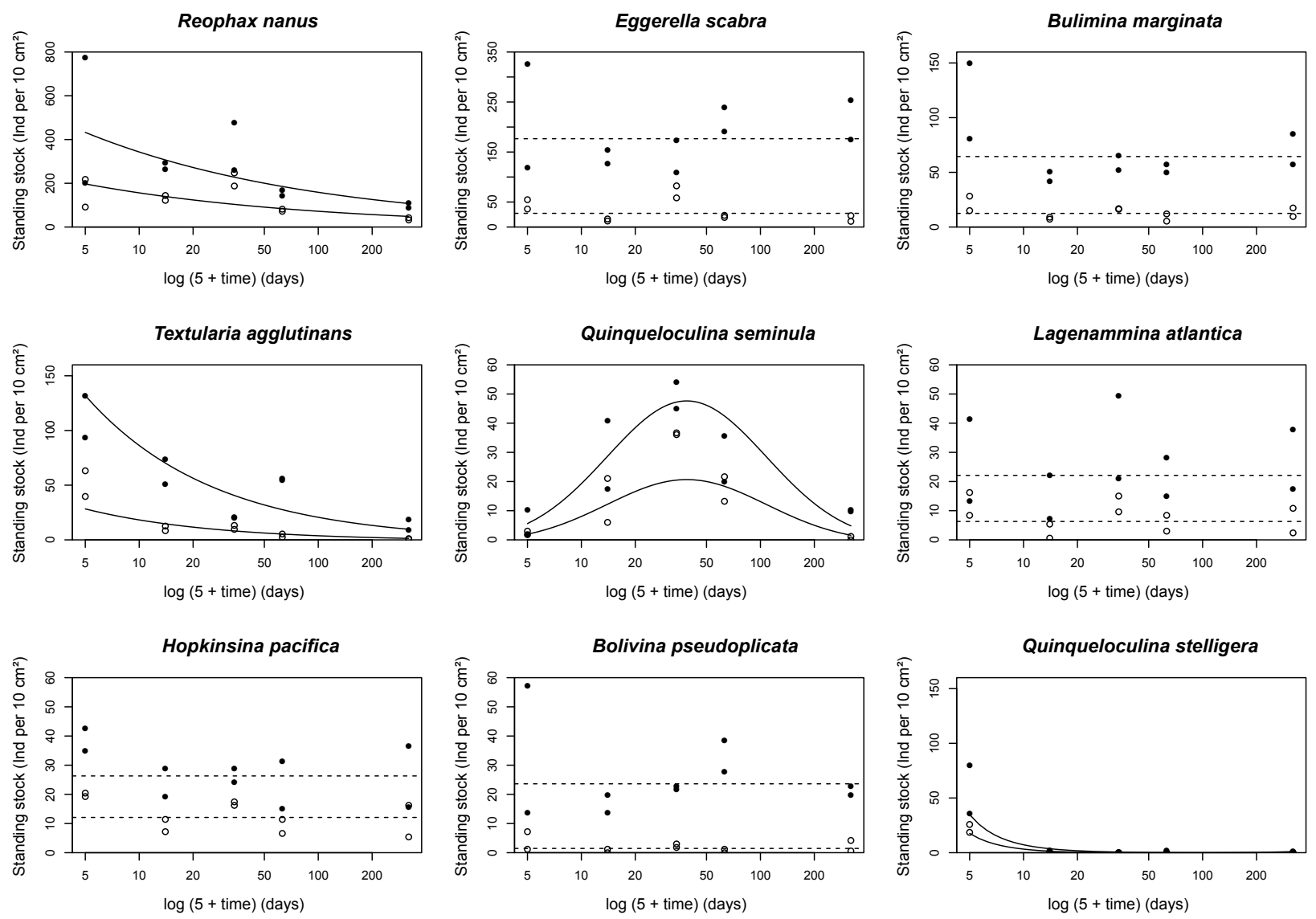

Fig. 3. Standing stock variation with time and sampling depth (full circles: $0-5 \mathrm{~cm}$, open circles $0-0.5 \mathrm{~cm}$ ) for the nine major species. The lines are estimated after the model-type 2, full lines indicating a significant effect of time and dashed lines indicating a nonsignificant effect of time. Two lines are drawn for the significantly different depth intervals.

per $10 \mathrm{~cm}^{2}$ in the "normoxia" cores to $\sim 15$ individuals per $10 \mathrm{~cm}^{2}$ in the "10 months" samples (Figs. 2 and 3). Quinqueloculina seminula showed a very different pattern. Standing stocks were low at the beginning and end of the experiment $\left(\sim 10\right.$ individuals per $\left.10 \mathrm{~cm}^{2}\right)$. There was a statistically significant increase (Table 4) towards maximum values of $\sim 50$ individuals per $10 \mathrm{~cm}^{2}$ in the "1 month" samples (Fig. 3) followed by a decrease down to $\sim 10$ individuals per $10 \mathrm{~cm}^{2}$ in the "10 months" samples.

Lagenammina atlantica, $H$. pacifica and B. pseudoplicata all varied between 15 and 60 individuals per $10 \mathrm{~cm}^{2}$ (Fig. 2). Lagenammina atlantica showed no clear changes with time, and the variability between replicate cores was high. The other two species showed a maximum in one of the "normoxia" cores. For none of these species was the change with time statistically significant (Table 4).

Finally, the standing stock of Quinqueloculina stelligera was 80 and 30 individuals per $10 \mathrm{~cm}^{2}$ in the 2 "normoxic" cores, but was less than 5 individuals per $10 \mathrm{~cm}^{2}$ in all anoxic cores from "9 days" to "10 months" (Fig. 2). Its standing stock decreased significantly with time and time ${ }^{2}$ (Fig. 3 and Table 4).

\subsection{Three different response types to long-term anoxia}

Based on the statistical tests presented in Table 4, we determined whether time and/or time ${ }^{2}$ had a significant relationship with the standing stocks of the dominant species. These test yielded three types of response (Table 5). The taxa of type A, which consist of R. nanus, T. agglutinans and Q. stelligera, all exhibited a significant decrease in standing stocks with time. Type B is composed of E. scabra, B. marginata, L. atlantica, $H$. pacifica and B. pseudoplicata, which did not exhibit a significant effect of time. Finally, response-type C contained only $Q$. seminula, which showed a significant effect of both time (positive) and time ${ }^{2}$ (negative); its standing stock significantly increased in the first month of the experiment, and decreased thereafter until the end of the experiment.

\subsection{Species microhabitats}

For most of the species, density decreased gradually with sediment depth (Fig. 4). Nevertheless, some species had fairly high densities at the sediment-water interface as well 
Table 4. Statistical parameters (Df: degrees of freedom; Sum Sq: sum of squares; Mean Sq: mean of squares; $F$ value: value of the $F$ test; $\operatorname{Pr}(>F)$ : probability of the $F$ test) for the model-type 2 for all the nine major species and for the standing stock.

\begin{tabular}{|c|c|c|c|c|c|c|}
\hline Species & $\begin{array}{l}\text { Independent } \\
\text { variable }\end{array}$ & Df & $\begin{array}{r}\text { Sum } \\
\text { Sq }\end{array}$ & $\begin{array}{r}\text { Mean } \\
\text { Sq }\end{array}$ & $\begin{array}{r}F \\
\text { value }\end{array}$ & $\begin{array}{r}\operatorname{Pr} \\
(>F)\end{array}$ \\
\hline \multirow[t]{3}{*}{ Reophax nanus } & $\log (5+$ time $)$ & 1 & 4.4 & 4.4 & 21.2 & $<10^{-3}$ \\
\hline & depth & 1 & 3.1 & 3.1 & 14.8 & 0.001 \\
\hline & residuals & 17 & 3.5 & 0.2 & NA & NA \\
\hline \multirow[t]{2}{*}{ Eggerella scabra } & depth & 1 & 16.8 & 16.8 & 60.1 & $<10^{-3}$ \\
\hline & residuals & 18 & 5.0 & 0.3 & NA & NA \\
\hline \multirow[t]{2}{*}{ Bulimina marginata } & depth & 1 & 12.5 & 12.5 & 75.1 & $<10^{-3}$ \\
\hline & residuals & 18 & 3.0 & 0.2 & NA & NA \\
\hline \multirow[t]{3}{*}{ Textularia agglutinans } & $\log (5+$ time $)$ & 1 & 14.5 & 14.5 & 60.1 & $<10^{-3}$ \\
\hline & depth & 1 & 11.4 & 11.4 & 47.4 & $<10^{-3}$ \\
\hline & residuals & 17 & 4.1 & 0.2 & NA & NA \\
\hline \multirow[t]{4}{*}{ Quinqueloculina seminula } & $\log (5+$ time $)$ & 1 & 0.1 & 0.1 & 0.3 & 0.58 \\
\hline & depth & 1 & 3.3 & 3.3 & 10.1 & 0.01 \\
\hline & $\log (5+\text { time })^{2}$ & 1 & 17.0 & 17.0 & 52.6 & $<10^{-3}$ \\
\hline & residuals & 16 & 5.2 & 0.3 & NA & NA \\
\hline \multirow[t]{2}{*}{ Lagenammina atlantica } & depth & 1 & 6.6 & 6.6 & 15.1 & 0.001 \\
\hline & residuals & 18 & 7.9 & 0.4 & NA & NA \\
\hline \multirow[t]{2}{*}{ Hopkinsina pacifica } & depth & 1 & 2.7 & 2.7 & 17.4 & 0.001 \\
\hline & residuals & 18 & 2.8 & 0.2 & NA & NA \\
\hline \multirow[t]{2}{*}{ Bolivina pseudoplicata } & depth & 1 & 26.5 & 26.5 & 83.9 & $<10^{-3}$ \\
\hline & residuals & 18 & 5.7 & 0.3 & NA & NA \\
\hline \multirow[t]{4}{*}{ Quinqueloculina stelligera } & $\log (5+$ time $)$ & 1 & 18.0 & 18.0 & 55.9 & $<10^{-3}$ \\
\hline & depth & 1 & 2.1 & 2.1 & 6.6 & 0.02 \\
\hline & $\log (5+\text { time })^{2}$ & 1 & 12.7 & 12.7 & 39.2 & $<10^{-3}$ \\
\hline & residuals & 16 & 5.2 & 0.3 & NA & NA \\
\hline
\end{tabular}

as deeper in the sediment (between 1.5 and $4 \mathrm{~cm}$ ). This was especially the case for response-type-B species. E. scabra and $B$. marginata, and to a minor degree $H$. pacifica, all showed maximum values both at the sediment-water interface and in a deeper sediment layer. Bolivina pseudoplicata showed a peak in the 0.5-2 depth interval, whereas $L$. atlantica and $Q$. stelligera showed fairly high densities from the sediment-water interface down to $2 \mathrm{~cm}$ depth (Fig. 4).

For all these species, no major change in the vertical distribution was recorded between the different sampling times (Fig. 4). A complementary statistical model indicated that only E. scabra, T. agglutinans, $Q$. seminula and $Q$. stelligera had significantly different vertical distributions at the different sampling times. These differences, however, were largely due to density changes in the $0-0.5 \mathrm{~cm}$ layer and did not appear to reflect a potential vertical migration of the foraminiferal faunas.
Table 5. Estimation of the coefficient associated with independent variables after model-type 2 for the nine major species. Only the independent variables having a significant effect on the standing stock are retained by the backward model selection. Depending on the presence or absence of a significant effect of time on the density and the coefficient sign, three types of responses have been determined.

\begin{tabular}{lcccc}
\hline Species & $\begin{array}{c}\text { Response } \\
\text { type }\end{array}$ & Time & Time $^{2}$ & Depth \\
\hline Textularia agglutinans & $\mathrm{A}$ & -0.61 & & -1.51 \\
Reophax nanus & $\mathrm{A}$ & -0.33 & & -0.78 \\
Quinqueloculina stelligera & $\mathrm{A}$ & -3.73 & 0.41 & -0.65 \\
Eggerella scabra & $\mathrm{B}$ & & & -1.83 \\
Bulimina marginata & $\mathrm{B}$ & & & -1.58 \\
Lagenammina atlantica & $\mathrm{B}$ & & & -1.15 \\
Hopkinsina pacifica & $\mathrm{B}$ & & & -0.74 \\
Bolivina pseudoplicata & $\mathrm{B}$ & & & -2.30 \\
Quinqueloculina seminula & $\mathrm{C}$ & 3.49 & -0.48 & -0.81 \\
\hline
\end{tabular}




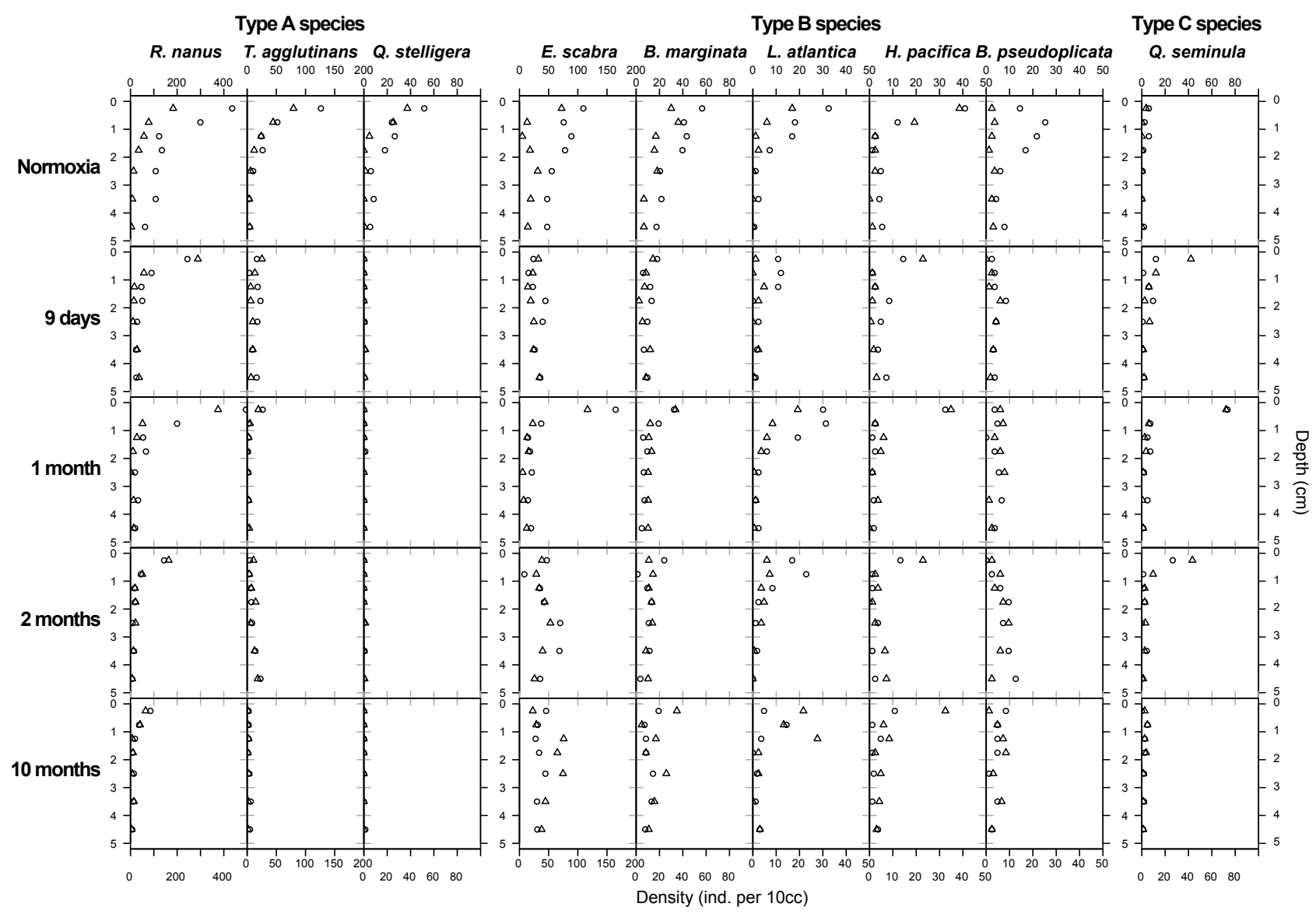

Fig. 4. Relationship between sediment depth and foraminiferal density for the nine major species at all sampling times. Open circles and triangles represent replicate cores 1 and 2 , respectively.

Table 6. Nitrate contents (in pmol) for seven different species of the two response-types A and B from two sampling sites (the Gulf of Trieste station Piran and the station D10 on the west coast of the Adriatic Sea). The number of tested individuals ( $n$ ), the number of individuals with a nitrate content different from 0 , the mean nitrate content, the minimum measured nitrate content, the minimum nitrate content different from 0 and the maximum measured nitrate content.

\begin{tabular}{llllllllr}
\hline & & & \multicolumn{7}{c}{ Nitrate content (pmol) } \\
\cline { 6 - 9 } Species & Type & Site & $n$ & $n(N \neq 0)$ & mean & min & $\min (N \neq 0)$ & $\max$ \\
\hline Leptohalysis scottii & A & Piran & 2 & 0 & 0 & 0 & - & 0 \\
Textularia agglutinans & A & Piran & 3 & 0 & 0 & 0 & - & 0 \\
Fissurina sp. & A & Piran & 1 & 0 & 0 & 0 & - & 0 \\
Nonion spp. & A & Piran & 2 & 0 & 0 & 0 & - & 0 \\
Ammonia beccarii & A & D10 & 4 & 0 & 0 & 0 & - & 0 \\
Eggerella scabra & B & Piran & 2 & 0 & 0 & 0 & - & 0 \\
Eggerella scabra & B & D10 & 9 & 3 & 22 & 0 & 37 & 119 \\
Bulimina marginata & B & Piran & 9 & 1 & 1 & 0 & 8 & 8 \\
Bulimina marginata & B & D10 & 1 & 1 & 433 & 433 & 433 & 433 \\
\hline
\end{tabular}

\subsection{Nitrate content and denitrification}

Only 5 of the 33 tested individuals from 7 different species contained nitrate in their cells (Table 6). Among the tested major species, the two $R$. nanus individuals did not have mea- surable nitrate in their cells. Also the two tested E. scabra individuals from "normoxic" conditions in Piran gave a negative result. Conversely, three of the nine tested E. scabra individuals from station D10 from the western Adriatic Sea showed a nitrate content varying between 37 and 119 pmol. 
Table 7. Denitrification rates of the two tested species from two different sites. The number of individuals added to the measurement chamber is indicated. In two cases some individuals were reused in a second set of measurements, generating pseudoreplication; the number of individuals used in the second set of measurements is indicated.

\begin{tabular}{|c|c|c|c|c|}
\hline Species & Site & $\begin{array}{l}\text { No. } \\
\text { indiv. }\end{array}$ & $\begin{array}{l}\text { Pseudo- } \\
\text { replication }\end{array}$ & $\begin{array}{l}\text { Rate (pmol } \\
\text { indv }^{-1} \mathrm{~d}^{-1} \text { ) }\end{array}$ \\
\hline Eggerella scabra & Piran & 4 & 4 indiv. (set 1) & 0 \\
\hline Eggerella scabra & Piran & 7 & 4 indiv. (set 2) & 0 \\
\hline Eggerella scabra & D10 & 7 & & 0 \\
\hline Bulimina marginata & Piran & 3 & 3 indiv. (set 1) & 0 \\
\hline Bulimina marginata & Piran & 6 & 3 indiv. (set 2) & 0 \\
\hline
\end{tabular}

One of the nine tested B. marginata specimens from Piran contained 8 pmol of nitrate, whereas the only tested individual from station D10 yielded 433 pmol (Table 6). None of the three tested $T$. agglutinans and the seven tested individuals of three nonmajor species (Fissurina sp., Nonion spp., Ammonia beccarii) contained any nitrate.

Several individuals of E. scabra and B. marginata were tested for their capacity to denitrify. None of the tests revealed denitrification (no detectible $\mathrm{N}_{2} \mathrm{O}$ production, Table 7).

\section{Discussion}

\subsection{Sediment geochemistry and faunal response to experimentally induced anoxia}

In this experiment, not only benthic foraminifera but also sediment geochemistry (Koron et al., 2013; Metzger et al., 2013), macrofaunal behavior (Blasnig et al., 2013; Riedel et al., 2013) and soft-shelled meiofauna (copepods and nematodes; De Troch et al., 2013; Grego et al., 2014) have been analyzed. Sediment geochemistry analyses enabled the development of the anoxia to be followed at the beginning of the experiment. The oxygen concentration started to decrease as soon as the chamber was closed, and anoxia was reached after 7 days, 2 days before the " 9 days" benthic chamber was sampled. The available geochemical information (Metzger et al., 2013) shows an upward migration of the redox fronts, indicating that the overlying water remained anoxic with reducing conditions until the end of the experiment (Fig. 5). The data also showed that nitrates were available in the pore water at all times (Koron et al., 2013).

At the beginning of the experiment, two to three brittle stars were placed in each chamber. The brittle stars died after 7 to 15 days of deployment, and shortly after their death the sediment surface turned black. After $\sim 5$ to 10 days, several infaunal organisms such as polychaetes and bivalves emerged from the sediment, finally dying on the sediment surface some days later. We hypothesize that the death of these macrofaunal organisms provided a considerable amount of fresh organic matter that was degraded by anaerobic pathways. The anaerobic degradation of this newly available organic matter released considerable amounts of hydrogen sulfides at the sediment-water interface and in the overlying water, which has been clearly observed in the "1 month" samples (Metzger et al., 2013).

In the present contribution we did not model the effect of geochemical changes on the foraminiferal response for three reasons: (1) different data set structures (the "2 months" samples were not analyzed in Metzger et al. (2013) and the vertical resolution of the geochemical measurements differs from that of the faunal analyses), (2) the impossibility to estimate benthic fluxes (due to the lack of stirring in the benthic chamber) and (3) statistical limitations (due to the strong intercorrelation of all the measured geochemical descriptors, making linear modeling impossible). Instead, we chose to first describe the temporal changes in the geochemical conditions to later quantify the effect of time on the foraminiferal faunas. This approach permits for indirect discussion (via the temporal changes) of the effect of the pore-water chemistry on the foraminiferal faunas.

\subsection{Variation of foraminiferal standing stocks and diversity}

The temporal variability of the total foraminiferal standing stock has been described in detail by Langlet et al. (2013). These authors concluded that - as shown by the statistical analyses - the variability appears to be explained by the changes in the experimental conditions rather than by spatial patchiness. Their data conclusively show that benthic foraminifera were alive at all the sampling times. Consequently, foraminifera can survive 10 months of anoxia. Nevertheless, the total foraminiferal standing stock significantly decreased with time, interrupted by slightly higher values in the "1 month" cores. Langlet et al. (2013) tentatively interpreted this increase as a response to organic matter release due to macrofaunal mortality.

A total of 74 taxa was observed. Since eight from the nine major species were found alive in all samples, even after 10 months of anoxia (Fig. 1), the changes in species richness are exclusively caused by minor species and by Quinqueloculina stelligera (which did not show any living individuals in one of the replicates cores of the " 1 month" and "10 months" chambers). Species richness of the whole cores significantly decreased with time, but for the $0-0.5 \mathrm{~cm}$ interval, this trend was not significant in the $>63 \mu \mathrm{m}$ fraction. This decrease is apparently explained by the disappearance of some of the less common species, which may be less resistant to the experimental conditions than the dominant species.

The two other diversity indices (Shannon index and evenness) show a significant decreasing trend only in the $>125 \mu \mathrm{m}$ fraction (Table 3 ). The lack of significant trends in the $>63 \mu \mathrm{m}$ fraction can be explained by the fact that the 


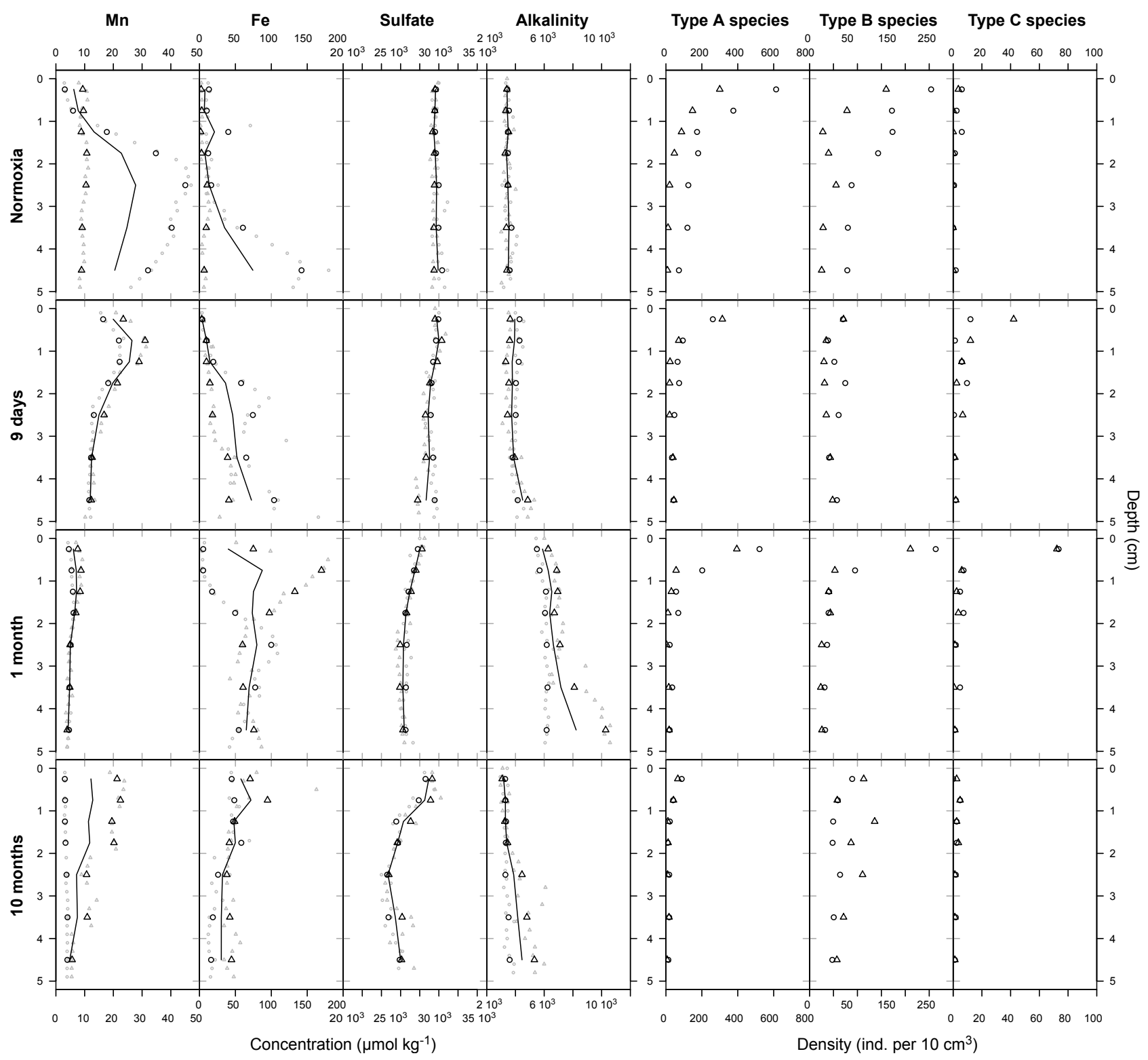

Fig. 5. Vertical profiles of dissolved manganese, iron, sulfates and alkalinity with sediment depth at all sampling points after data presented in Metzger et al. (2013) and vertical profiles of the total densities of the type A, B and C species. The raw geochemistry data are presented as small, grey open circles and triangles for the two replicate probes. Large, black open circle: concentration values averaged for each depth interval $(0-0.5 \mathrm{~cm}, \ldots 4-5 \mathrm{~cm})$. Black line: average for both replicates. The foraminiferal densities are presented as open circles and triangles for cores 1 and 2 , respectively.

faunas of the small size fraction $(63-125 \mu \mathrm{m})$ were dominated (up to $>40 \%$ ) by Reophax nanus (Fig. 2). The absolute as well as relative frequency of this species decreased with time (Supplement 1,2 and 3), leading to a higher evenness and Shannon index for the fine fraction; this may compensate for the significant decreasing tendency of these indices in the $>125 \mu \mathrm{m}$ fraction.

In general, the diversity of foraminiferal assemblages is low in permanently hypoxic areas, such as oxygen minimum zones (OMZs; reviewed in Koho and Piña-Ochoa, 2012), as well as in seasonally hypoxic areas, such as the Gulf of Mexico (Blackwelder et al., 1996) or the shallow Skagerrak coast (Nordberg et al., 2000; Filipsson and Nordberg, 2004; Bouchet et al., 2012). In this context, it is surprising that the decrease in foraminiferal diversity with time is not clearer in our data. 
Table 8. Type of environment, microhabitat, and response to anoxia in the literature and in the present study for all the major species (their synonymous names are also given). Abbreviations: $\mathrm{O}_{2}$ represents oxygen or oxygenated; OM, organic matter; $N$, density or standing stock; relativ., relatively; and $\mathrm{M}$, months.

\begin{tabular}{|c|c|c|c|c|c|c|}
\hline \multirow[b]{2}{*}{ Species } & \multirow[b]{2}{*}{$\begin{array}{l}\text { Other } \\
\text { names }\end{array}$} & \multicolumn{3}{|c|}{ Literature } & \multicolumn{2}{|c|}{ Present study } \\
\hline & & Distribution & Microhabitat & $\begin{array}{l}\text { Response } \\
\text { to anoxia }\end{array}$ & $\begin{array}{l}\text { Micro- } \\
\text { habitat }\end{array}$ & $\begin{array}{l}\text { Response } \\
\text { to anoxia }\end{array}$ \\
\hline \multirow[t]{6}{*}{$\begin{array}{l}\text { Reophax } \\
\text { nanus }\end{array}$} & R. nana & Coastal environments & $\begin{array}{l}\text { Deep infaunal } \\
(8,9,10)\end{array}$ & $\begin{array}{l}\text { Tolerant to low } \mathrm{O}_{2} \\
\text { (11) }\end{array}$ & $\begin{array}{l}\text { Shallow } \\
\text { infaunal }\end{array}$ & Type A \\
\hline & $\begin{array}{l}\text { Cuneata } \\
\text { arctica }\end{array}$ & Vigo Estuary (1) & $\begin{array}{l}\text { Shallow infaunal } \\
(1,6)\end{array}$ & $\begin{array}{l}\text { Indicator of OM-rich } \\
(12,13)\end{array}$ & & Decrease in $N$ \\
\hline & $\begin{array}{l}\text { Acostata } \\
\text { mariae }\end{array}$ & Skagerrak (2) & & $\begin{array}{l}\text { No change in } N \text { in } \\
\text { low } \mathrm{O}_{2}(9,10)\end{array}$ & & $\begin{array}{l}\mathrm{N} \text { relativ. high } \\
\text { after } 10 \text { months }\end{array}$ \\
\hline & & Mediterranean shelf (3) & & $\begin{array}{l}\text { Decrease in } N \text { in } \\
\text { anoxia }(14,15)\end{array}$ & & \\
\hline & & Adriatic Sea $(4,5)$ & & & & \\
\hline & & Gulf of Trieste $(6,7)$ & & & & \\
\hline \multirow{4}{*}{$\begin{array}{l}\text { Textularia } \\
\text { agglutinans }\end{array}$} & & Coastal environments & Unclear & In $\mathrm{O}_{2}$ sediments $(5,17)$ & Shallow & Type A \\
\hline & & Mediterranean Sea & Deep infaunal (9) & $\begin{array}{l}\text { No change in } N \text { in } \\
\text { low } \mathrm{O}_{2}(9)\end{array}$ & infaunal & Decrease in $N$ \\
\hline & & Rhône Prodelta $(16,17)$ & & & & \\
\hline & & Adriatic Sea $(18,19,20,7)$ & & & & \\
\hline \multirow{3}{*}{$\begin{array}{l}\text { Quinqueloculina } \\
\text { stelligera }\end{array}$} & & Coastal environments & & Undescribed & Shallow & Type A \\
\hline & & Gulf of Cadiz (21) & & $\begin{array}{l}\text { Considered an indicator } \\
\text { of high } \mathrm{O}_{2}(24)\end{array}$ & infaunal & $\begin{array}{l}\text { Strong decrease } \\
\text { in } N\end{array}$ \\
\hline & & Mediterranean Sea (22) & & & & \\
\hline \multirow[t]{2}{*}{$\begin{array}{l}\text { Eggerella } \\
\text { scabra }\end{array}$} & $\begin{array}{l}\text { Eggerelloides } \\
\text { scabra }\end{array}$ & $\begin{array}{l}\text { Subtidal, coastal and shelf } \\
\text { environments }(1,25)\end{array}$ & $\begin{array}{l}\text { Infaunal } \\
(4,8,9,18)\end{array}$ & $\begin{array}{l}\text { Tolerant to hypoxia } \\
\text { and anoxia }(1,8)\end{array}$ & $\begin{array}{l}\text { Deep } \\
\text { infaunal }\end{array}$ & Type B \\
\hline & & Adriatic Sea $(4,6,7,26,27)$ & & $\begin{array}{l}\text { Increase in } N \text { in } \\
\text { hypoxia }(28)\end{array}$ & & No change in $N$ \\
\hline \multirow[t]{5}{*}{$\begin{array}{l}\text { Bulimina } \\
\text { marginata }\end{array}$} & B. aculeata & Cosmopolitan & Unclear (34) & $\begin{array}{l}\text { Can survive episodes of } \\
\text { severe hypoxia/anoxia } \\
(4,5,28,35)\end{array}$ & $\begin{array}{l}\text { Deep } \\
\text { infaunal }\end{array}$ & Type B \\
\hline & B. denudata & Atlantic Ocean (29) & Shallow infaunal & & & No change in $N$ \\
\hline & & Mediterranean Sea $(5,10$, & Intermediate & & & \\
\hline & & $16,30,31,32,33)$ & infaunal & & & \\
\hline & & $\begin{array}{l}\text { Adriatic Sea (18) } \\
\text { Gulf of Trieste (6) }\end{array}$ & Deep infaunal & & & \\
\hline \multirow[t]{2}{*}{$\begin{array}{l}\text { Lagenammina } \\
\text { atlantica }\end{array}$} & $\begin{array}{l}\text { Saccammina } \\
\text { atlantica }\end{array}$ & Continental shelves (25) & & & $\begin{array}{l}\text { Shallow/ } \\
\text { intermediate }\end{array}$ & Type B \\
\hline & & Brackish waters (25) & & & infaunal & No change in $N$ \\
\hline \multirow[t]{2}{*}{$\begin{array}{l}\text { Hopkinsina } \\
\text { pacifica }\end{array}$} & $\begin{array}{l}\text { Hopkinsinella } \\
\text { glabra }\end{array}$ & $\begin{array}{l}\text { River-influenced inner } \\
\text { shelf }(1,4,16,18)\end{array}$ & $\begin{array}{l}\text { Shallow infaunal } \\
(9,10,18)\end{array}$ & $\begin{array}{l}\text { Can survive in } \\
\text { anoxia (10) }\end{array}$ & $\begin{array}{l}\text { Shallow } \\
\text { infaunal }\end{array}$ & Type B \\
\hline & $\begin{array}{l}\text { Hopkinsina } \\
\text { atlantica }\end{array}$ & $\begin{array}{l}\text { Northern Adriatic Sea } \\
(6,8,9,10,14,20)\end{array}$ & & & & No change in $N$ \\
\hline \multirow[t]{2}{*}{$\begin{array}{l}\text { Bolivina } \\
\text { pseudoplicata }\end{array}$} & & $\begin{array}{l}\text { Transitional environments } \\
(1,36,37)\end{array}$ & & & $\begin{array}{l}\text { Deep } \\
\text { infaunal }\end{array}$ & Type B \\
\hline & & Adriatic Sea $(6,19)$ & & & & No change in $N$ \\
\hline \multirow[t]{4}{*}{$\begin{array}{l}\text { Quinqueloculina } \\
\text { seminula }\end{array}$} & & Continental shelves (25) & & $\begin{array}{l}\text { Sensitive to } \\
\text { anoxia (15) }\end{array}$ & $\begin{array}{l}\text { Shallow } \\
\text { infaunal }\end{array}$ & Type C \\
\hline & & Mediterranean lagoons (25) & & & & $\begin{array}{l}\text { Opportunistic } \\
\text { response to OM }\end{array}$ \\
\hline & & Adriatic Sea (38) & & & & \\
\hline & & Gulf of Trieste (6) & & & & \\
\hline References & & & & & & \\
\hline
\end{tabular}

1: Diz and Francés (2008), 2: Alve and Goldstein (2010), 3: Hyams-Kaphzan et al. (2009), 4: Barmawidjaja et al. (1992), 5: Donnici and Serandrei Barbero (2002), 6: Hohenegger et al. (1993), 7: Sabbatini et al. (2010), 8: Ernst et al. (2002), 9: Duijnstee et al. (2003), 10: Ernst et al. (2005), 11: Semensatto Jr. et al. (2009), 12: Scott et al. (2001), 13: Mojtahid et al. (2008), 14: Moodley et al. (1997), 15: Moodley et al. (1998), 16: Mojtahid et al. (2009), 17: Goineau et al. (2011), 18: Jorissen et al. (1992), 19: Barmawidjaja et al. (1995), 20: Duijnstee et al. (2004), 21: Mendes et al. (2012), 22: Mateu-Vicens et al. (2010), 23: Celia Magno et al. (2012), 24: Di Bella et al. (2011), 25: Murray (2006), 26: Stigter et al. (1998), 27: Sabbatini et al. (2012), 28: Pucci et al. (2009), 29: Jorissen et al. (1998), 30: Jorissen (1987), 31: De Rijk et al. (2000), 32: Di Leonardo et al. (2007), 33: Schmiedl et al. (2000), 34: Jorissen (1999), 35: Geslin et al. (2014), 36: Cearreta et al. (2000), 37: Debenay et al. (2006), 38: Frontalini and Coccioni (2011) 


\subsection{Species responses to experimentally induced anoxia}

Based on the temporal variability of the standing stocks of individual taxa, three types of responses to anoxia have been recognized: the taxa of type A show a significant decrease with time, for the species of type B there is no significant trend, and $Q$. seminula is the only species of type $\mathrm{C}$ that shows a significant maximum in the " 1 month" cores. The next chapter considers all species of these three response types in more detail, in the hope that our observations may contribute to a better understanding of their ecology. For 65 taxa the relative frequency is always lower than $4 \%$. These taxa have been arbitrarily separated into seven taxonomic groups. Four groups show a significant decrease in their cumulative standing stocks with time: (1) Ammonia/Aubignina spp., (2) Elphidium/Nonion/Haynesina spp., (3) non-fossilizing agglutinated taxa and (4) miliolids. Conversely, (1) bolivinids, (2) buliminids and (3) the group of epiphytic taxa do not show a significant decrease in cumulative standing stocks with time.

In the following subsections we discuss the changes of standing stock and the vertical migration for each of the major species of each response type. The discussion on each species is summarized in Table 8.

\subsubsection{Response-type A}

Response-type A is composed of R. nanus, T. agglutinans and $Q$. stelligera. The first two species, which are the most dominant in the assemblages, are both agglutinants, whereas Quinqueloculina stelligera has a porcelaneous shell. All three species show a significant decrease in standing stock with time (Fig. 3 and Table 4). Therefore they appear to be sensitive to the experimental conditions of long-lasting anoxia with a presence of hydrogen sulfides.

Sediment geochemistry data presented in Metzger et al. (2013) show a clear upward migration of the production fronts of dissolved manganese, iron and alkalinity and of the sulfate consumption front (see Fig. 5). This upward migration of the redox fronts appears gradually with the experiment duration. In parallel, the foraminiferal vertical distribution shows that at all sampling times, species from type A are present primarily at the sediment-water interface. These type-A species do not show any major sign of vertical migration with time (Fig. 5). Therefore, they do not seem to track the sediment geochemistry changes. The anoxia-sensitive character of these species might explain their incapacity to move and migrate in anoxic conditions.

\section{Reophax nanus}

Reophax nanus is present mainly in the $63-125 \mu \mathrm{m}$ size fraction. This species appears to be sensitive to the experimental conditions (Fig. 3 and Table 4). In spite of the centrifugation treatment applied to separate the soft-shelled meiofauna from both the hard-shelled meiofauna and the sediment lattice, Reophax nanus was present in large numbers at all sampling times. It could have been expected that the centrifugation treatment would destroy very fragile foraminiferal species such as $R$. nanus. In spite of the large numbers, our density and standing stock estimates of this species might be slightly underestimated. It has been previously described under different names (Reophax nana, Cuneata arctica or often Acostata mariae) and is common in coastal environments such as the Skagerrak (Alve and Goldstein, 2010), the northeastern Mediterranean shelf (Hyams-Kaphzan et al., 2009) or in low densities in the Vigo Estuary (Diz and Francés, 2008). This species is found frequently in the Adriatic Sea (Barmawidjaja et al., 1992; Donnici and Serandrei Barbero, 2002) and, more specifically, in the Gulf of Trieste (Hohenegger et al., 1993; Sabbatini et al., 2010).

Reophax nanus has been described mostly in eutrophic places such as mudflats in a Brazilian mangrove (Semensatto Jr. et al., 2009), where the authors suggested that it could be tolerant to exposure to low oxygenation. This species has also been considered a good bio-indicator of organic-rich conditions (Scott et al., 2001; Mojtahid et al., 2008). Several experiments were conducted to identify the effect of low oxygen concentration on the Adriatic Sea faunas. Some studies reported that the density of $R$. nanus was not influenced by low-oxygen conditions (Duijnstee et al., 2003; Ernst et al., 2005). Conversely, in other assays of rose-bengal-stained assemblages, lower densities were observed in anoxia with and without co-occurring hydrogen sulfides (Moodley et al., 1997, 1998). In summary, although the response of this species to low-oxygen settings is not clear in the literature, in the present study it shows a clear decrease in standing stock with time.

Reophax nanus was described earlier as a deep infaunal species and can potentially reproduce deep in the sediment (Ernst et al., 2002, 2005; Duijnstee et al., 2003), while in the present study, in Diz and Francés (2008) and in Hohenegger et al. (1993), R. nanus is found mostly in the shallowest first centimeter of the sediment. This species migrated upward in response to an organic matter pulse in well-oxygenated conditions (Ernst et al., 2005).

Despite its apparent sensitivity to anoxia, $R$. nanus is still alive in substantial numbers after 10 months of anoxia. We can therefore confirm that although it prefers welloxygenated settings, $R$. nanus is able to survive anoxia with co-occurring hydrogen sulfides. Nonetheless, the significant decrease in its relative frequencies (Supplement 2 and 3) suggests that it is less resistant than most other dominant species.

\section{Textularia agglutinans}

Textularia agglutinans was found alive in all size fractions, with larger numbers in the $63-125 \mu \mathrm{m}$ fraction (Fig. 2). Its standing stock significantly diminishes with time, and in the sediment column it quickly disappears in deeper levels 
(Figs. 3 and 4 and Table 4). Both observations suggest a limited tolerance of anoxia. Textularia agglutinans has been widely described in the Mediterranean, for instance in the Rhônee Prodelta (Mojtahid et al., 2009; Goineau et al., 2011), the Marmara Sea (Armynot du Châtelet et al., 2013) and also in the Adriatic Sea (Jorissen et al., 1992; Barmawidjaja et al., 1995; Duijnstee et al., 2004; Sabbatini et al., 2010). Its ecological preferences are not well established. Duijnstee et al. (2003) described it as a deep-dwelling species showing no vertical migration or standing stock changes in experimentally induced anoxia. Conversely, T. agglutinans is common in the distal zone of the Rhône Prodelta, where the surface sediment is well oxygenated and where the oxygen penetration depth is relatively high (Goineau et al., 2011). It is also abundant in less eutrophic and better-oxygenated areas off the Po Delta (Donnici and Serandrei Barbero, 2002). Most of these observations corroborate our conclusion that T. agglutinans is sensitive to bottom-water anoxia and cooccurring hydrogen sulfides.

\section{Quinqueloculina stelligera}

Quinqueloculina stelligera is found alive only in the finest size fraction (63-125 $\mu \mathrm{m}$, Fig. 2). Its standing stocks show a strong and significant decrease with time, as it is almost exclusively found alive in the "normoxic" conditions (Fig. 3 and Table 4). In these well-oxygenated conditions it lives in the two upper centimeters of the sediment (Fig. 4). Quinqueloculina stelligera has been described from infralittoral areas in the Gulf of Cadiz (Mendes et al., 2012) and in low quantities in sediment colonized by Posidonia oceanica in the Mediterranean Sea (Mateu-Vicens et al., 2010). In the Tyrrhenian Sea, its distribution seems to be controlled by sediment type, since it is almost exclusively found on fine sands (Celia Magno et al., 2012). However, Q. stelligera is also described in stations polluted with $\mathrm{Fe}, \mathrm{Pb}, \mathrm{Zn}$ and polycyclic aromatic hydrocarbons and was consequently considered pollution-tolerant (Romano et al., 2009). Although it appears to be resistant to heavy-metal pollution, it has not been described before in low-oxygen environments. Consequently, in a paleontological record of the ancient harbor of Claudius, the presence of $Q$. stelligera was interpreted as indicative of a well-oxygenated environment (Di Bella et al., 2011). In the present study, the instantaneous (and significant) collapse of its standing stocks early in the experiment suggests that it is highly sensitive to anoxia.

\subsubsection{Response-type B}

Response-type B is composed of two agglutinated species (E. scabra and L. atlantica) and three calcareous species (B. marginata, H. pacifica and B. pseudoplicata). The standing stocks of these taxa do not decrease significantly with time (Fig. 3 and Table 4), suggesting strong resistance to the experimental conditions.
The vertical distribution of the type-B species shows that they are found living at all sampling depths at all times. In the "9 days", "2 months" and "10 months" samples their densities are comparable at all depths, while in "normoxia" and in the "1 month" samples their vertical distributions show both considerable densities in deeper sediment layers and a peak at the sediment-water interface (Fig. 5). This peculiar distribution could reflect organic matter availability. As explained above, we suspect that organic matter availability is larger in "normoxic" conditions and after 1 month of the experiment, due to aerobic and anaerobic degradation and the decay of the dead macrofauna. The anoxia-resistant species would therefore show a peak density at the sediment-water interface when the organic matter availability was maximal there. Consequently, these species seem to track changes in the organic-matter availability rather than changes in the porewater chemistry. In our first paper we suggested that organicmatter availability is the main parameter explaining changes of the foraminiferal standing stocks (Langlet et al., 2013). Many previous studies show a clear response of foraminiferal faunas to organic matter input (Heinz et al., 2001; Ernst and van der Zwaan, 2004; Duijnstee et al., 2005; Ernst et al., 2005; Nomaki et al., 2005; Pucci et al., 2009). We now also suspect that the foraminiferal vertical distribution is more likely explained by changes in the organic matter availability than by the development of anoxia and by changes in porewater chemistry.

\section{Eggerella scabra}

In the present study, Eggerella scabra (also known as Eggerelloides scabra; Hohenegger et al., 1993; Diz and Francés, 2008) is present in all size fractions from 63 to $315 \mu \mathrm{m}$ (Fig. 2). Its standing stock does not change significantly with time (Fig. 3 and Table 4). It penetrates relatively deep into the sediment, showing substantial numbers down to $5 \mathrm{~cm}$ depth (Fig. 4). Eggerella scabra is a very common species in subtidal, coastal and shelf environments (Murray, 2006; Diz and Francés, 2008), and is a common species in the Adriatic Sea (Jorissen et al., 1992; Hohenegger et al., 1993; Stigter et al., 1998; Sabbatini et al., 2010, 2012). It has been reported in sediments rich in organic matter (Stigter et al., 1998; Donnici and Serandrei Barbero, 2002), more specifically in sediments with low-quality organic matter (Diz and Francés, 2008; Duchemin et al., 2008; Goineau et al., 2011). Eggerella scabra has also been considered to be tolerant to hypoxic and/or anoxic conditions (Ernst et al., 2002; Diz and Francés, 2008). In a laboratory experiment, Pucci et al. (2009) observed an increased standing stock of E. scabra after a 15-day incubation in strongly hypoxic conditions. $E g$ gerella scabra is generally described as an infaunal species (Barmawidjaja et al., 1992; Jorissen et al., 1992; Ernst et al., 2002; Duijnstee et al., 2003). As in our cores, it is often found throughout the first $5 \mathrm{~cm}$ of the sediment column without a clear maximum at a specific depth (Ernst et al., 2006; Pucci 
et al., 2009). Our data clearly confirm the capacity of $E g$ gerella scabra to survive anoxia with co-occurring hydrogen sulfides. This species can be considered highly resistant to such anoxic conditions.

\section{Bulimina marginata}

Bulimina marginata was alive in all size fractions from 63 to $315 \mu \mathrm{m}$ and showed no significant change in its standing stock with time (Figs. 2 and 3 and Table 4). This cosmopolitan taxon is well known in the Atlantic Ocean (e.g., Jorissen et al., 1998) and Mediterranean Sea (e.g., Jorissen, 1987; De Rijk et al., 2000; Schmiedl et al., 2000; Donnici and Serandrei Barbero, 2002; Ernst et al., 2005; Di Leonardo et al., 2007; Mojtahid et al., 2009). It occurs in continental shelf and slope environments, and abundant faunas have been described from the Adriatic Sea (e.g., Jorissen et al., 1992) and especially from the Gulf of Trieste (Hohenegger et al., 1993). Jorissen (1988) noted that three main morphotypes occur in the Adriatic Sea. Typical morphotypes, with welldeveloped undercuts, occur in outer shelf and upper slope settings. Bulimina aculeata morphotypes with a fusiform, slightly twisted initial part are found mainly on the continental shelf, whereas $B$. denudata morphotypes with weakly developed undercuts are dominant at eutrophic inner-shelf sites (Jorissen, 1988). Based on molecular phylogenetic analyses, Tsuchiya et al. (2008) concluded that these morphotypes are genetically different and should be considered biological species. In our material, denudata and aculeata types dominated.

Bulimina marginata is generally considered to be an eutrophic taxon typical for areas with high organic carbon loads, where it may show an opportunistic behavior (Zwaan and Jorissen, 1991; Schmiedl et al., 2000; Donnici and Serandrei Barbero, 2002; Langezaal et al., 2006; Mojtahid et al., 2006). Because this taxon can survive episodes of severe hypoxia/anoxia (Barmawidjaja et al., 1992; Donnici and Serandrei Barbero, 2002; Pucci et al., 2009; Geslin et al., 2014), it is generally considered stress-tolerant, although some authors suggested that it may prefer well-oxygenated conditions (Alve and Bernhard, 1995; Donnici and Serandrei Barbero, 2002; Ernst et al., 2005; Mojtahid et al., 2006). Our observations, with no significant changes in standing stocks after 10 months of anoxia, fully confirm its resistance to anoxia with a presence of hydrogen sulfides.

The microhabitat of Bulimina marginata is not well defined. In the literature, it has been described as a shallow, intermediate or even deep infaunal taxon (see review in Jorissen, 1999). Bulimina marginata may find suitable environmental conditions at the sediment surface as well as deeper in the sediment. In our study, abundant occurrences in deeper sediment intervals confirm its potentially infaunal character (Fig. 4).

Several authors have suggested that Bulimina marginata can migrate rapidly through the sediment, which could ex- plain their often chaotic vertical distribution (Barmawidjaja et al., 1992; Mackensen et al., 2000; Schmiedl et al., 2000; Ernst et al., 2005). In a laboratory experiment with strongly hypoxic conditions, however, it did not migrate vertically (Pucci et al., 2009). Alve and Bernhard (1995) considered Bulimina marginata as one of the few taxa potentially able to reproduce in strongly hypoxic conditions. In the present study, it is clearly strongly resistant to anoxia and cooccurring hydrogen sulfides, but its rather invariable standing stocks provide no indications that reproduction occurred during the 10 months of our experiment.

\section{Lagenammina atlantica}

Lagenammina atlantica (also known as Saccammina atlantica) was mainly found alive in the $150-315 \mu \mathrm{m}$ fraction. Its standing stocks differ considerably between the pairs of replicate cores, and there is no significant overall change with time (Figs. 2 and 3 and Table 4). Most individuals were found in the first $1.5 \mathrm{~cm}$ (Fig. 4). Little information is available about the ecology of this taxon. Murray (2006) considers it to be a shelf species that also inhabits brackish waters. Our data strongly suggest that this species is very resistant to the combination of anoxia and hydrogen sulfide.

\section{Hopkinsina pacifica}

Hopkinsina pacifica (also named Hopkinsinella glabra (Haig, 1993) or Hopkinsina atlantica (Diz and Francés, 2008)) was found alive mainly in the $63-125 \mu \mathrm{m}$ fraction. Its standing stocks show no significant trend with time. Unlike the other species of response-type B, H. pacifica is mainly found at the sediment-water interface, and is apparently a surface dweller. Hopkinsinella pacifica is a typical species of river-influenced inner-shelf ecosystems (Barmawidjaja et al., 1992; Jorissen et al., 1992; Diz and Francés, 2008; Mojtahid et al., 2009) such as in the northern Adriatic Sea (Hohenegger et al., 1993; Moodley et al., 1997; Ernst et al., 2002, 2005; Duijnstee et al., 2003, 2004).

On the basis of a laboratory experiment, Ernst et al. (2005) concluded that this species is favored by fresh food supplies. Other observations corroborate such an opportunistic behavior (Jorissen et al., 1992; Ernst et al., 2002; Duijnstee et al., 2004; Goineau et al., 2012), which is a common trait of several small-sized taxa (e.g., Epistominella exigua, Leptohalysis scottii). Hopkinsina pacifica typically occupies the superficial sediment layer (Jorissen et al., 1992; Ernst et al., 2002; Duijnstee et al., 2003). Our observations confirm that this species is a surface dweller. In an experimental study involving an organic matter pulse under anoxic conditions, Ernst et al. (2005) observed an upward migration of this taxon. In our experiment, living individuals were always restricted to the upper $1 \mathrm{~cm}$, and no upward migration was observed (Fig. 4).

Ernst et al. (2005) reported that only part of their H. pacifica population survived experimental anoxia. In our data, 
this species showed no significant decrease with time, and it belongs to the most anoxia-resistant taxonomic group.

\section{Bolivina pseudoplicata}

Bolivina pseudoplicata is mainly found in the $63-125 \mu \mathrm{m}$ fraction and, like the other representatives of responsetype $\mathrm{B}$, its standing stocks do not show a significant change with time. Bolivina pseudoplicata occurs in fair numbers down to $5 \mathrm{~cm}$ depth without a clear trend.

Bolivina pseudoplicata has been reported from transitional environments such as estuaries and prodeltas (Cearreta et al., 2000; Debenay et al., 2006; Diz and Francés, 2008). This species has also been observed in the Adriatic Sea (Hohenegger et al., 1993; Barmawidjaja et al., 1995). Its ecology is not well known and little information is available about its microhabitat. Our data, which show abundant living individuals after 10 months of anoxia, demonstrate its high anoxia tolerance.

\subsubsection{Response-type C}

\section{Quinqueloculina seminula}

Quinqueloculina seminula represents response-type C. It is found mostly in the $63-125 \mu \mathrm{m}$ size fraction and occurs only in the topmost centimeter of the sediment, indicating a very shallow microhabitat. Quinqueloculina seminula is only present in small quantities in the "normoxia" core samples at the beginning of the experiment, but shows a 10-fold increase in standing stock after 9 days, reaching a density maximum after 1 month. Thereafter, standing stocks decrease, and after 10 months of anoxia, standing stocks are comparable to those in the "normoxia" cores.

Quinqueloculina seminula has been described from a wide range of environments, such as Mediterranean lagoons, marshes and continental shelves (reviewed in Murray, 2006). Species of the genus Quinqueloculina are also common in the Adriatic Sea (Frontalini and Coccioni, 2011) and in the Gulf of Trieste (Hohenegger et al., 1993). Concerning its tolerance to low-oxygen conditions, contradictory evidence has been reported. For example, Moodley and Hess (1992) observed that it was resistant to $24 \mathrm{~h}$ of anoxia, whereas a later study described it as sensitive to anoxia with co-occurring hydrogen sulfides (Moodley et al., 1998). Rather surprisingly in view of the general perception of miliolids as sensitive taxa that are typical of oligotrophic conditions (e.g., Barras et al., 2014), $Q$. seminula has been observed to be an early colonizer after volcanic ash deposits (Hess and Kuhnt, 1996) and a pioneer species after sediment disturbance in submarine canyons (Duros et al., 2011).

Our observations suggest an opportunistic response to labile organic matter supplies combined with a resistance to short-term anoxia. As explained above, we hypothesize that the increase in standing stocks of several taxa in the "1 month" cores, which is particularly spectacular for Q. seminula, is a response to increased labile organic matter availability after macrofaunal mortality in the first two weeks of the experiment. In the subsequent weeks (i.e., after the sampling of the "9 days" cores), the anaerobic degradation of this organic matter released a large quantity of hydrogen sulfides that can be observed at the sediment-water interface in the " 1 month" chamber. We hypothesize that the increase in the standing stocks during the first month of the experiment is due to growth of juvenile specimens (individuals $<63 \mu \mathrm{m}$ ) or is the result of a reproduction event triggered by the accumulation of labile organic matter at the sedimentwater interface. The decrease in density between 1 and 10 months of experiment could reflect a combined effect of less organic matter availability (that is, mainly consumed anaerobically after the onset of anoxia), the effect of prolonged anoxia and the sensitivity to hydrogen sulfides, which appeared massively in the water column.

Quinqueloculina seminula can therefore tentatively be considered as a species with an opportunistic behavior, capable of surviving the early stages of anoxia, but sensitive to prolonged anoxia in combination with sulfides.

\subsection{Foraminiferal community response to the experimental conditions}

Considering the response of the whole foraminiferal community, the impact of 10 months of anoxia, with co-occurring hydrogen sulfides, is apparently very limited. This is not really surprising because most of the dominant taxa are known for their resistance to low-oxygen conditions, which is largely confirmed by our results. This dominance of lowoxygen-tolerant taxa is logical in ecosystems that are periodically impacted by seasonal hypoxia. Seasonal hypoxia has increased in frequency over the last 50 years, reflecting strongly increased anthropogenic nutrient inputs, but is basically a natural phenomenon (Barmawidjaja et al., 1995; Diaz and Rosenberg, 2008). In spite of the overall tolerance of low-oxygen conditions, which is evident for all major species (which all survived 10 months of anoxia), three differential types of response have been distinguished. The species of response-type A (Reophax nanus, Textularia agglutinans and Quinqueloculina stelligera), which is mainly composed of rather superficially living species, show a significant decrease in standing stock, although many living specimens remain until the end of the experiment. The species of response-type B (Eggerella scabra, Bulimina marginata, Lagenammina atlantica, Hopkinsina pacifica and Bolivina pseudoplicata), which is mainly composed of taxa with a stronger infaunal tendency, show an even higher tolerance for the combination of prolonged anoxia and hydrogen sulfide, and show no significant decline in standing stocks with time. This higher tolerance may be partly explained by their deeper microhabitats, which forces these taxa to live in anoxic conditions even when the sediment-water interface 
Table 9. Statistical parameters (Df: degrees of freedom; Sum Sq: sum of squares; Mean Sq: mean of squares; $F$ value: value of the $F$ test; Pr $(>F)$ : probability of the $F$ test) for the model-type 3 for all three response types and for the two tested dependant variables (standing stock and frequency).

\begin{tabular}{|c|c|c|c|c|c|c|c|}
\hline $\begin{array}{l}\text { Dependent } \\
\text { variable }\end{array}$ & Response & $\begin{array}{l}\text { Independent } \\
\text { variable }\end{array}$ & Df & $\begin{array}{c}\text { Sum } \\
\text { Sq }\end{array}$ & $\begin{array}{c}\text { Mean } \\
\text { Sq }\end{array}$ & $\begin{array}{c}F \\
\text { value }\end{array}$ & $\begin{array}{c}\operatorname{Pr} \\
(>F)\end{array}$ \\
\hline \multirow{7}{*}{$\begin{array}{l}\text { Standing } \\
\text { stock }\end{array}$} & \multirow[t]{2}{*}{ Type A } & $\log (5+$ time $)$ & 1 & 2.8 & 2.8 & 22.1 & 0.002 \\
\hline & & residuals & 8 & 1.0 & 0.1 & NA & NA \\
\hline & \multirow[t]{2}{*}{ Type B } & $\log (5+$ time $)$ & 1 & 0.0 & 0.0 & 0.0 & 0.92 \\
\hline & & residuals & 8 & 0.9 & 0.1 & NA & NA \\
\hline & \multirow[t]{3}{*}{ Type C } & $\log (5+$ time $)$ & 1 & 0.2 & 0.2 & 0.7 & 0.43 \\
\hline & & $\log (5+\text { time })^{2}$ & 1 & 5.4 & 5.4 & 19.5 & 0.003 \\
\hline & & residuals & 7 & 1.9 & 0.3 & NA & NA \\
\hline \multirow{7}{*}{$\begin{array}{l}\text { Relative } \\
\text { frequency }\end{array}$} & \multirow[t]{2}{*}{ Type A } & $\log (5+$ time $)$ & 1 & 0.1 & 0.1 & 27.9 & 0.001 \\
\hline & & residuals & 8 & 0.0 & 0.0 & NA & NA \\
\hline & \multirow[t]{2}{*}{ Type B } & $\log (5+$ time $)$ & 1 & 0.1 & 0.1 & 21.7 & 0.002 \\
\hline & & residuals & 8 & 0.0 & 0.0 & NA & NA \\
\hline & \multirow[t]{3}{*}{ Type C } & $\log (5+$ time $)$ & 1 & 0.0 & 0.0 & 0.4 & 0.56 \\
\hline & & $\log (5+\text { time })^{2}$ & 1 & 0.0 & 0.0 & 15.9 & 0.01 \\
\hline & & residuals & 7 & 0.0 & 0.0 & NA & NA \\
\hline
\end{tabular}

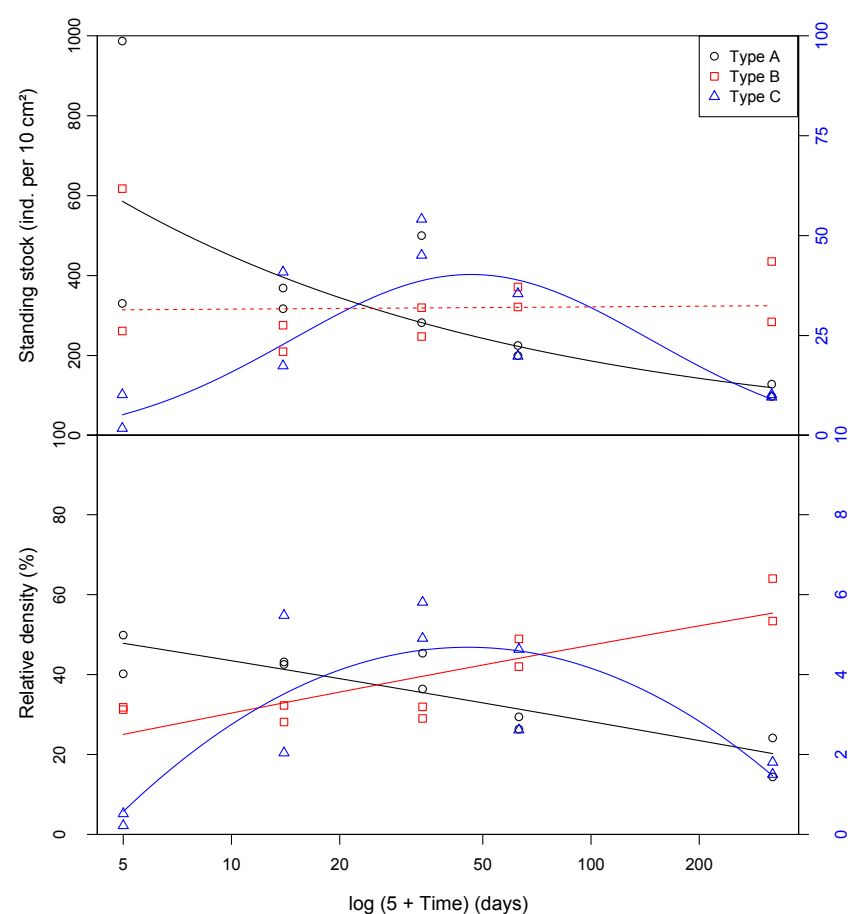

Fig. 6. Standing stock (upper panel) and relative density (lower panel) variation with time for the three types of response (black circles: type A; red squares: type B; and blue triangles: type C) in the whole core $(0-5 \mathrm{~cm})$. Note that for representation purposes the standing stocks and relative density of type $\mathrm{C}$ were multiplied by 10 (refer to axis on the right). The lines are estimated after the model-type 3, with full lines indicating a significant effect of time and dashed lines a nonsignificant effect. is oxic. Conversely, their higher tolerance to anoxia also enables them to live in deeper sediment intervals; this is important in ecosystems where oxygen penetration is normally limited to the upper few millimeters (Metzger et al., 2013).

Finally, the shallow infaunal taxon $Q$. seminula combines the slightly lower tolerance to anoxic conditions of the response-type-A taxa with a very strong opportunistic tendency. The result is a spectacular increase in standing stock after 1 month. Surprisingly, the presence of anoxia did not inhibit a reproductive response of this species to inputs of labile organic matter.

Examining the behavior of these three types of responses enabled three successive stages to be distinguished. Figure 6 shows that during the first stage, until the second or third week, the faunas tend to be dominated by response-type-A species. During the second stage, which lasts until about the second month, $Q$. seminula, and perhaps also Reophax nanus and Lagenammina atlantica, show an opportunistic response (reproduction and growth) to putative labile organic carbon input resulting from the death of enclosed macrofauna. The third and final stage shows an increasing dominance of the highly anoxia-resistant response-type-B species (Fig. 6 and Table 9). This three-stage temporal succession is very similar to the spatial patterns along strong eutrophication gradients, such as those described around point sources of organic pollution. Along such gradients, sensitive taxa progressively disappear, and slightly stress-tolerant taxa are gradually replaced by taxa with maximum tolerance for stressed conditions. When stress is not lethal, some species may show a strong opportunistic response, yielding very high standing stocks. Such patterns have been described repeatedly for macrofauna (e.g., Pearson and Rosenberg, 1976), but have recently also be shown for foraminifera (Mojtahid et al., 2006, 
2008). In summary, the foraminiferal response to anoxia and co-occurring enrichment in organic matter appears to be very similar to the macrofaunal response, with the essential difference that many foraminiferal taxa are much more resistant to anoxic conditions than macrofauna (Langlet et al., 2013).

\subsection{Understanding foraminiferal survival during exposure to anoxia}

The intracellular nitrate content and denitrification measurements could not be performed for all the major species of our study area, mainly because of the difficulty in selecting living foraminifera in the silty and sandy sediments of our two sampling stations. Nevertheless, intracellular nitrate measurements are available for species of each of the three identified response types. We performed measurements on species from response-types $\mathrm{A}$ and $\mathrm{B}$, whereas the genus Quinqueloculina was tested by Piña-Ochoa et al. (2010). Our results show that none of the 12 tested individuals of 5 species belonging to response-type A were able to accumulate nitrate in their cells. Conversely, 5 of the tested 21 individuals of E. scabra and B. marginata, both belonging to response-type B, contained non-negligible amounts of intracellular nitrates, with values ranging from 8 to $433 \mathrm{pmol}$ per cell. Unfortunately, no data are available for the three other species of response-type B (L. atlantica, H. pacifica and B. pseudoplicata). Piña-Ochoa et al. (2010) measured 16 specimens (from the Peru OMZ, Skagerrak, Bay of Biscay and Rhône Delta) of Quinqueloculina spp. without obtaining any positive results. Although the available information is still inconclusive, a picture emerges that response-type-B species can accumulate nitrate in their cytoplasm, whereas response-type-A species and $Q$. seminula cannot. Although this picture remains to be confirmed by additional measurements, the present data suggest that the higher tolerance to anoxia by the response-type-B species could reflect their ability to accumulate nitrate and thus to shift to an anaerobic metabolism (denitrification) under anoxic conditions. Nonetheless, the five measurements of denitrification we performed for E. scabra and B. marginata gave only negative results. We see two possible explanations for the absence of denitrification in these experiments: (1) the measured individuals did not accumulate nitrate before being measured, perhaps because the well-oxygenated pre-measurement laboratory conditions did not incite them to do so, or (2) they are incapable of denitrifying. This calls for additional analyses to establish whether the foraminiferal taxa that survive 10 months of anoxia are capable of denitrifying or not. If not, another explanation must be sought for their highly surprising long-term survival.

\section{Conclusions}

We performed an in situ experiment at a 24 m-deep site in the Gulf of Trieste. Benthic chambers were installed on the sediment surface and rapidly turned anoxic. Cores sampled in chambers opened after 9 days, 1 month, 2 months and 10 months all contained abundant foraminiferal assemblages down to $5 \mathrm{~cm}$ depth in the sediment. During the experiment the foraminiferal species richness significantly decreased, while the diversity indices showed no changes, probably due to the anoxia sensitivity of Reophax nanus, which was strongly dominant in the original conditions. Despite the minor changes in diversity, the species composition changed because some species are less resistant than others to anoxia. The present study identified Reophax nanus, Textularia agglutinans and especially Quinqueloculina stelligera as more sensitive to the experimental conditions. Conversely, Eggerella scabra, Bulimina marginata, Lagenammina atlantica, Hopkinsina pacifica and Bolivina pseudoplicata appear to be highly resistant to long-term anoxia and cooccurring hydrogen sulfide. The change in species composition by foraminiferal faunas was not the only response: some taxa also apparently show an opportunistic behavior with the release of organic matter due to the degradation of the dead macrofauna after 1 month of experimentation. Quinqueloculina seminula, (and perhaps also Reophax nanus and Lagenammina atlantica) exhibit such a potentially opportunistic behavior. Finally, the intracellular nitrate and denitrification measurements we performed provided no positive evidence that foraminiferal survival to anoxia is related to their denitrification capacity. This differential reaction to anoxia, and the survival of set of species to long-term disturbance, has important implications for the status and recovery potential of coastal areas increasingly affected by large-scale oxygendepletion events.

\section{Supplementary material related to this article is available online at http://www.biogeosciences.net/11/ 1775/2014/bg-11-1775-2014-supplement.zip.}


Acknowledgements. The authors would like to thank Joan Bernhard, who edited this paper and the special issue, and two anonymous reviewers for their constructive comments, which helped us to improve the manuscript. The first author's research is funded by the General Council of the Region Pays de la Loire. This study is funded by the Austrian Science Fund (FWF project P21542-B17 and P17655-B03), and supported by the OEAD "Scientific-Technical Cooperation" between Austria and France (project FR 13/2010) and between Austria and Slovenia (project SI 22/2009). The first author greatly profited from the support of the Cushman Foundation for Foraminiferal Research, the European project Erasmus and the Danish National Research Foundation, which made it possible to perform intracellular nitrate analyses at Aarhus University. We would like to thank the director and staff of the Marine Biology Station Piran for their support during this project, all the scuba divers for their involvement during the fieldwork, Karim Issa and Erica Bicchi for the precious technical assistance and Grégoire Lognoné for his helpful contribution to the data acquisition.

\section{Edited by: J. Bernhard}

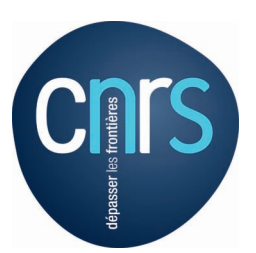

The publication of this article is financed by CNRS-INSU.

\section{References}

Alve, E. and Bernhard, J.: Vertical migratory response of benthic foraminifera to controlled oxygen concentrations in an experimental mesocosm, Mar. Ecol.-Prog. Ser., 116, 137-151, doi:10.3354/meps116137, 1995.

Alve, E. and Goldstein, S. T.: Dispersal, survival and delayed growth of benthic foraminiferal propagules, J. Sea Res., 63, 36$51,2010$.

Andersen, K., Kjær, T., and Revsbech, N. P.: An oxygen insensitive microsensor for nitrous oxide, Sens. Actuators B Chem., 81, 4248, doi:10.1016/S0925-4005(01)00924-8, 2001.

Armynot du Châtelet, E., Bout-Roumazeilles, V., Coccioni, R., Frontalini, F., Guillot, F., Kaminski, M. A., Recourt, P., Riboulleau, A., Trentesaux, A., Tribovillard, N., and Ventalon, S.: Environmental control on shell structure and composition of agglutinated foraminifera along a proximal-distal transect in the Marmara Sea, Mar. Geol., 335, 114-128, doi:10.1016/j.margeo.2012.10.013, 2013.

Barmawidjaja, D. M., Jorissen, F. J., Puskaric, S., and van der Zwaan, G. J.: Microhabitat selection by benthic Foraminifera in the northern Adriatic Sea, J. Foraminifer. Res., 22, 297-317, doi:10.2113/gsjfr.22.4.297, 1992.

Barmawidjaja, D., Van der Zwaan, G., Jorissen, F., and Puskaric, S.: 150 years of eutrophication in the northern Adriatic Sea: evidence from a benthic foraminiferal record, Mar. Geol., 122, 367384, 1995.

Barras, C., Jorissen, F. J., Labrune, C., Andral, B., and Boissery, P.: Live benthic foraminiferal faunas from the French Mediterranean
Coast: Towards a new biotic index of environmental quality, Ecol. Indic., 36, 719-743, doi:10.1016/j.ecolind.2013.09.028, 2014.

Bernhard, J. M.: Postmortem Vital Staining in Benthic Foraminifera; Duration and Importance in Population and Distributional Studies, J. Foraminifer. Res., 18, 143-146, doi:10.2113/gsjfr.18.2.143, 1988.

Bernhard, J. M.: Distinguishing Live from Dead Foraminifera: Methods Review and Proper Applications, Micropaleontology, 46, 38-46, 2000.

Bernhard, J. M. and Reimers, C. E.: Benthic foraminiferal population fluctuations related to anoxia: Santa Barbara Basin, Biogeochemistry, 15, 127-149, doi:10.1007/BF00003221, 1991.

Bernhard, J. M. and Sen Gupta, B. K.: Foraminifera of oxygen-depleted environments, in Modern Foraminifera, 201216, Springer Netherlands, available at: http://link.springer. com/chapter/10.1007/0-306-48104-9_12 (last access: 12 March 2013), 1999.

Bernhard, J. M., Ostermann, D. R., Williams, D. S., and Blanks, J. K.: Comparison of two methods to identify live benthic foraminifera: A test between Rose Bengal and CellTracker Green with implications for stable isotope paleoreconstructions, Paleoceanography, 21, PA4210, doi:10.1029/2006PA001290, 2006.

Bernhard, J. M., Casciotti, K. L., McIlvin, M. R., Beaudoin, D. J., Visscher, P. T., and Edgcomb, V. P.: Potential importance of physiologically diverse benthic foraminifera in sedimentary nitrate storage and respiration, J. Geophys. Res., 117, G03002, doi:10.1029/2012JG001949, 2012.

Blackwelder, P., Hood, T., Alvarez-Zarikian, C., Nelsen, T. A., and McKee, B.: Benthic foraminifera from the NECOP study area impacted by the Mississippi River plume and seasonal hypoxia, Quat. Int., 31, 19-36, doi:10.1016/1040-6182(95)00018E, 1996.

Blasnig, M., Riedel, B., Zuschin, M., Schiemer, L., and Stachowitsch, M.: Short-term post-mortality predation and scavenging and longer-term recovery after anoxia in the northern Adriatic Sea, Biogeosciences Discuss., 10, 4367-4401, doi:10.5194/bgd10-4367-2013, 2013.

Boltovskoy, E. and Lena, H.: On the Decomposition of the Protoplasm and the Sinking Velocity of the Planktonic Foraminifers, Int. Rev. Gesamten Hydrobiol. Hydrogr., 55, 797804, doi:10.1002/iroh.19700550507, 1970.

Bouchet, V. M. P., Alve, E., Rygg, B., and Telford, R. J.: Benthic foraminifera provide a promising tool for ecological quality assessment of marine waters, Ecol. Indic., 23, 66-75, doi:10.1016/j.ecolind.2012.03.011, 2012.

Burdige, D. J.: Geochemistry of marine sediments, Princeton University Press., 2006.

Burgess, R.: An improved protocol for separating meiofauna from sediments using colloidal silica sols, Mar. Ecol.-Prog. Ser., 214, 161-165, 2001.

Cearreta, A., Irabien, M. J., Leorri, E., Yusta, I., Croudace, I. W., and Cundy, A. B.: Recent Anthropogenic Impacts on the Bilbao Estuary, Northern Spain: Geochemical and Microfaunal Evidence, Estuar. Coast. Shelf S., 50, 571-592, doi:10.1006/ecss.1999.0582, 2000.

Celia Magno, M., Bergamin, L., Finoia, M. G., Pierfranceschi, G., Venti, F., and Romano, E.: Correlation between textural characteristics of marine sediments and benthic foraminifera in highly 
anthropogenically-altered coastal areas, Mar. Geol., 315-318, 143-161, doi:10.1016/j.margeo.2012.04.002, 2012.

Chambers, J. M. and Hastie, T.: Statistical models in S, Chapman \& Hall London, available at: http://www.lavoisier.fr/livre/notice. asp?id=OKRW3SA2OKOOWW (last access: 12 March 2013), 1992.

Debenay, J.-P., Bicchi, E., Goubert, E., and Armynot du Châtelet, E.: Spatio-temporal distribution of benthic foraminifera in relation to estuarine dynamics (Vie estuary, Vendée, W France), Estuar. Coast. Shelf S., 67, 181-197, doi:10.1016/j.ecss.2005.11.014, 2006.

De Rijk, S., Jorissen, F. J., Rohling, E. J., and Troelstra, S. R.: Organic flux control on bathymetric zonation of Mediterranean benthic foraminifera, Mar. Micropaleontol., 40, 151-166, doi:10.1016/S0377-8398(00)00037-2, 2000.

de Stigter, H. C., Jorissen, F. J., van der and Zwaan, G. J.: Bathymetric distribution and microhabitat partitioning of live (Rose Bengal stained) benthic Foraminifera along a shelf to bathyal transect in the southern Adriatic Sea, J. Foraminifer. Res., 28, 40-65, 1998.

De Troch, M., Roelofs, M., Riedel, B., and Grego, M.: Structural and functional responses of harpacticoid copepods to anoxia in the Northern Adriatic: an experimental approach, Biogeosciences, 10, 4259-4272, doi:10.5194/bg-10-4259-2013, 2013.

Diaz, R. J. and Rosenberg, R.: Spreading dead zones and consequences for marine ecosystems, Science, 321, 926-929, 2008.

Di Bella, L., Bellotti, P., Frezza, V., Bergamin, L., and Carboni, M. G.: Benthic foraminiferal assemblages of the imperial harbor of Claudius (Rome): Further paleoenvironmental and geoarcheological evidences, The Holocene, 21, 1245-1259, doi:10.1177/0959683611405239, 2011.

Di Leonardo, R., Bellanca, A., Capotondi, L., Cundy, A., and Neri, R.: Possible impacts of $\mathrm{Hg}$ and $\mathrm{PAH}$ contamination on benthic foraminiferal assemblages: An example from the Sicilian coast, central Mediterranean, Sci. Total Environ., 388, 168-183, doi:10.1016/j.scitotenv.2007.08.009, 2007.

Diz, P. and Francés, G.: Distribution of live benthic foraminifera in the Ría de Vigo (NW Spain), Mar. Micropaleontol., 66, 165-191, doi:10.1016/j.marmicro.2007.09.001, 2008.

Donnici, S. and Serandrei Barbero, R.: The benthic foraminiferal communities of the northern Adriatic continental shelf, Mar. Micropaleontol., 44, 93-123, doi:10.1016/S0377-8398(01)000433, 2002.

Duchemin, G., Jorissen, F. J., Le Loc'h, F., Andrieux-Loyer, F., Hily, C., and Thouzeau, G.: Seasonal variability of living benthic foraminifera from the outer continental shelf of the Bay of Biscay, J. Sea Res., 59, 297-319, doi:10.1016/j.seares.2008.03.006, 2008.

Duijnstee, I. A. P., de Nooijer, L. J., Ernst, S. R., and van der Zwaan, G. J.: Population dynamics of benthic shallow-water foraminifera: effects of a simulated marine snow event, Mar. Ecol.-Prog. Ser., 285, 29-42, 2005.

Duijnstee, I., Ernst, S., and Van der Zwaan, G.: Effect of anoxia on the vertical migration of benthic foraminifera, Mar. Ecol.-Prog. Ser., 246, 85-94, 2003.

Duijnstee, I., de Lugt, I., Vonk Noordegraaf, H., and van der Zwaan, B.: Temporal variability of foraminiferal densities in the northern Adriatic Sea, Mar. Micropaleontol., 50, 125-148, doi:10.1016/S0377-8398(03)00069-0, 2004.
Duros, P., Fontanier, C., Metzger, E., Pusceddu, A., Cesbron, F., de Stigter, H. C., Bianchelli, S., Danovaro, R., and Jorissen, F. J.: Live (stained) benthic foraminifera in the Whittard Canyon, Celtic margin (NE Atlantic), Deep-Sea Res. Pt. I, 58, 128-146, doi:10.1016/j.dsr.2010.11.008, 2011.

Ernst, S. and van der Zwaan, B.: Effects of experimentally induced raised levels of organic flux and oxygen depletion on a continental slope benthic foraminiferal community, Deep Sea Res. Part Oceanogr. Res. Pap., 51, 1709-1739, doi:10.1016/j.dsr.2004.06.003, 2004.

Ernst, S., Duijnstee, I., and van der Zwaan, B.: The dynamics of the benthic foraminiferal microhabitat: recovery after experimental disturbance, Mar. Micropaleontol., 46, 343-361, doi:10.1016/S0377-8398(02)00080-4, 2002.

Ernst, S., Bours, R., Duijnstee, I., and van der Zwaan, B.: Experimental effects of an organic matter pulse and oxygen depletion on a benthic foraminiferal shelf community, J. Foraminifer. Res., 35, 177-197, doi:10.2113/35.3.177, 2005.

Ernst, S. R., Morvan, J., Geslin, E., Le Bihan, A., and Jorissen, F. J.: Benthic foraminiferal response to experimentally induced Erika oil pollution, Mar. Micropaleontol., 61, 76-93, doi:10.1016/j.marmicro.2006.05.005, 2006.

Faganeli, J., Avčin, A., Fanuko, N., Malej, A., Turk, V., Tušnik, P., Vrišer, B., and Vukovič, A.: Bottom layer anoxia in the central part of the Gulf of Trieste in the late summer of 1983, Mar. Pollut. Bull., 16, 75-78, doi:10.1016/0025-326X(85)90127-4, 1985.

Filipsson, H. L. and Nordberg, K.: Climate variations, an overlooked factor influencing the recent marine environment. An example from Gullmar Fjord, Sweden, illustrated by benthic foraminifera and hydrographic data, Estuar. Coasts, 27, 867-881, 2004.

Frontalini, F. and Coccioni, R.: Benthic foraminifera as bioindicators of pollution: A review of Italian research over the last three decades, Rev. Micropaléontol., 54, 115-127, doi:10.1016/j.revmic.2011.03.001, 2011.

Geslin, E., Barras, C., Langlet, D., Kim, J.-H., Bonnin, J., Metzger, E., and Jorissen, F. J.: Survival, Reproduction and Calcification of Three Benthic Foraminiferal Species in Response to Experimentally Induced Hypoxia, in: Experimental Approaches in Foraminifera: Collection, Maintenance and Experiments, edited by: Bernhard, J. and Kitazato, H., Berlin, 2014.

Giani, M., Djakovac, T., Degobbis, D., Cozzi, S., Solidoro, C., and Umani, S. F.: Recent changes in the marine ecosystems of the northern Adriatic Sea, Estuar. Coast. Shelf S., 115, 1-13, doi:10.1016/j.ecss.2012.08.023, 2012.

Glud, R. N.: Oxygen dynamics of marine sediments, Mar. Biol. Res., 4, 243-289, doi:10.1080/17451000801888726, 2008.

Goineau, A., Fontanier, C., Jorissen, F. J., Lansard, B., Buscail, R., Mouret, A., Kerhervé, P., Zaragosi, S., Ernoult, E., Artéro, C., Anschutz, P., Metzger, E., and Rabouille, C.: Live (stained) benthic foraminifera from the Rhône prodelta (Gulf of Lion, NW Mediterranean): Environmental controls on a river-dominated shelf, J. Sea Res., 65, 58-75, doi:10.1016/j.seares.2010.07.007, 2011.

Goineau, A., Fontanier, C., Jorissen, F., Buscail, R., Kerhervé, P., Cathalot, C., Pruski, A. M., Lantoine, F., Bourgeois, S., Metzger, E., Legrand, E., and Rabouille, C.: Temporal variability of live (stained) benthic foraminiferal faunas in a river-dominated shelf - Faunal response to rapid changes of the river influence 
(Rhône prodelta, NW Mediterranean), Biogeosciences, 9, 13671388, doi:10.5194/bg-9-1367-2012, 2012.

Grego, M., Riedel, B., Stachowitsch, M., and De Troch, M.: Meiofauna winners and losers of coastal hypoxia: case study harpacticoid copepods, Biogeosciences, 11, 281-292, doi:10.5194/bg11-281-2014, 2014.

Haig, D. W.: Buliminid foraminifera from inner neritic sand and mud facies of the Papuan Lagoon, New Guinea, J. Foraminifer. Res., 23, 162-179, doi:10.2113/gsjfr.23.3.162, 1993.

Hannah, F. and Rogerson, A.: The Temporal and Spatial Distribution of Foraminiferans in Marine Benthic Sediments of the Clyde Sea Area, Scotland, Estuar. Coast. Shelf S., 44, 377-383, 1997.

Hayek, L.-A. C. and Buzas, M. A.: Surveying Natural Populations, Columbia University Press, 1997.

Heinz, P., Kitazato, H., Schmiedl, G., and Hemleben, C.: Response of Deep-Sea Benthic Foraminifera from the Mediterranean Sea to Simulated Phytoplankton Pulses Under Laboratory Conditions, J. Foraminifer. Res., 31, 210-227, doi:10.2113/31.3.210, 2001.

Helly, J. J. and Levin, L. A.: Global distribution of naturally occurring marine hypoxia on continental margins, Deep-Sea Res. Pt. I, 51, 1159-1168, doi:10.1016/j.dsr.2004.03.009, 2004.

Hess, S. and Kuhnt, W.: Deep-sea benthic foraminiferal recolonization of the $1991 \mathrm{Mt}$. Pinatubo ash layer in the South China Sea, Mar. Micropaleontol., 28, 171-197, doi:10.1016/03778398(95)00080-1, 1996.

Høgslund, S., Revsbech, N. P., Cedhagen, T., Nielsen, L. P., and Gallardo, V. A.: Denitrification, nitrate turnover, and aerobic respiration by benthic foraminiferans in the oxygen minimum zone off Chile, J. Exp. Mar. Biol. Ecol., 359, 85-91, 2008.

Hohenegger, J., Piller, W., and Baal, C.: Reasons for Spatial Microdistributions of Foraminifers in an Intertidal Pool (Northern Adriatic Sea), Mar. Ecol., 10, 43-78, doi:10.1111/j.14390485.1989.tb00065.x, 1989.

Hohenegger, J., Piller, W. E., and Baal, C.: Horizontal and vertical spatial microdistribution of foraminifers in the shallow subtidal Gulf of Trieste, northern Adriatic Sea, J. Foraminifer. Res., 23, 79-101, doi:10.2113/gsjfr.23.2.79, 1993.

Hyams-Kaphzan, O., Almogi-Labin, A., Benjamini, C., and Herut, B.: Natural oligotrophy vs. pollution-induced eutrophy on the SE Mediterranean shallow shelf (Israel): Environmental parameters and benthic foraminifera, Mar. Pollut. Bull., 58, 1888-1902, doi:10.1016/j.marpolbul.2009.07.010, 2009.

Jorissen, F. J.: The distribution of benthic foraminifera in the Adriatic Sea, Mar. Micropaleontol., 12, 21-48, doi:10.1016/03778398(87)90012-0, 1987.

Jorissen, F. J.: Benthic foraminifera from the Adriatic Sea?: principles of phenotypic variation, Utrecht Micropaleontol. Bull., 37, 176 pp., 1988.

Jorissen, F. J.: Benthic foraminiferal microhabitats below the sediment-water interface, in Modern Foraminifera, 161-179, Springer Netherlands, available at: http://link.springer.com/ chapter/10.1007/0-306-48104-9_10 (last access: 12 March 2013), 1999.

Jorissen, F. J., Barmawidjaja, D. M., Puskaric, S., and van der Zwaan, G. J.: Vertical distribution of benthic foraminifera in the northern Adriatic Sea: The relation with the organic flux, Mar. Micropaleontol., 19, 131-146, doi:10.1016/03778398(92)90025-F, 1992.
Jorissen, F. J., Wittling, I., Peypouquet, J. P., Rabouille, C., and Relexans, J. C.: Live benthic foraminiferal faunas off Cape Blanc, NW-Africa: Community structure and microhabitats, Deep Sea Res. Pt. I, 45, 2157-2188, doi:10.1016/S09670637(98)00056-9, 1998.

Koho, K. A. and Piña-Ochoa, E.: Benthic Foraminifera: Inhabitants of Low-Oxygen Environments, in Anoxia, edited by: Altenbach, A. V., Bernhard, J. M., and Seckbach, J., 249285, Springer Netherlands, available at: http://link.springer.com/ chapter/10.1007/978-94-007-1896-8_14 (last access: 20 February 2013), 2012.

Koron, N., Ogrinc, N., Metzger, E., Riedel, B., and Faganeli, J.: Diagenesis and benthic fluxes of nutrients and metals during experimentally induced anoxia in the Gulf of Trieste (northern Adriatic Sea), Biogeosciences Discuss., 10, 11729-11755, doi:10.5194/bgd-10-11729-2013, 2013.

Langezaal, A. M., Jorissen, F. J., Braun, B., Chaillou, G., Fontanier, C., Anschutz, P., and van der Zwaan, G. J.: The influence of seasonal processes on geochemical profiles and foraminiferal assemblages on the outer shelf of the Bay of Biscay, Cont. Shelf Res., 26, 1730-1755, doi:10.1016/j.csr.2006.05.005, 2006.

Langlet, D., Geslin, E., Baal, C., Metzger, E., Lejzerowicz, F., Riedel, B., Zuschin, M., Pawlowski, J., Stachowitsch, M., and Jorissen, F. J.: Foraminiferal survival after long-term in situ experimentally induced anoxia, Biogeosciences, 10, 7463-7480, doi:10.5194/bg-10-7463-2013, 2013.

Mackensen, A., Schumacher, S., Radke, J., and Schmidt, D. N.: Microhabitat preferences and stable carbon isotopes of endobenthic foraminifera: clue to quantitative reconstruction of oceanic new production?, Mar. Micropaleontol., 40, 233-258, doi:10.1016/S0377-8398(00)00040-2, 2000.

Malej, A. and Malacic, V.: Factors affecting bottom layer oxygen depletion in the Gulf of Trieste (Adriatic Sea), Ann. Istrske Mediter. Stud. Hist. Nat., 6, 33-42, 1995.

Mateu-Vicens, G., Box, A., Deudero, S., and Rodríguez, B.: Comparative Analysis of Epiphytic Foraminifera in Sediments Colonized by Seagrass Posidonia oceanica and Invasive Macroalgae Caulerpa spp., J. Foraminifer. Res., 40, 134-147, doi:10.2113/gsjfr.40.2.134, 2010.

McIntyre, A. D. and Warwick, R. M.: Meiofauna techniques, in: Methods for the Study of Marine Benthos, edited by: Holme, N. A. and McIntyre, A. D., Oxford, 217-244, 1984.

Mendes, I., Dias, J. A., Schönfeld, J., and Ferreira, Ó.: Distribution of living benthic foraminifera on the northern gulf of Cadiz continental shelf, J. Foraminifer. Res., 42, 18-38, doi:10.2113/gsjfr.42.1.18, 2012.

Metzger, E., Langlet, D., Viollier, E., Koron, N., Riedel, B., Stachowitsch, M., Faganeli, J., Tharaud, M., Geslin, E., and Jorissen, F.: Artificially induced migration of redox layers in a coastal sediment from the Northern Adriatic, Biogeosciences Discuss., 10, 12029-12063, doi:10.5194/bgd-10-12029-2013, 2013.

Middelburg, J. J. and Levin, L. A.: Coastal hypoxia and sediment biogeochemistry, Biogeosciences, 6, 1273-1293, doi:10.5194/bg-6-1273-2009, 2009.

Mojtahid, M., Jorissen, F., Durrieu, J., Galgani, F., Howa, H., Redois, F., and Camps, R.: Benthic foraminifera as bioindicators of drill cutting disposal in tropical east Atlantic outer shelf environments, Mar. Micropaleontol., 61, 58-75, doi:10.1016/j.marmicro.2006.05.004, 2006. 
Mojtahid, M., Jorissen, F., and Pearson, T. H.: Comparison of benthic foraminiferal and macrofaunal responses to organic pollution in the Firth of Clyde (Scotland), Mar. Pollut. Bull., 56, 4276, doi:10.1016/j.marpolbul.2007.08.018, 2008.

Mojtahid, M., Jorissen, F., Lansard, B., Fontanier, C., Bombled, B., and Rabouille, C.: Spatial distribution of live benthic foraminifera in the Rhône prodelta: Faunal response to a continental-marine organic matter gradient, Mar. Micropaleontol., 70, 177-200, doi:10.1016/j.marmicro.2008.12.006, 2009.

Moodley, L. and Hess, C.: Tolerance of infaunal benthic foraminifera for low and high oxygen concentrations, Biol. Bull., 183, 94-98, 1992.

Moodley, L., van der Zwaan, G. J., Herman, P. M. J., Kempers, L., and van Breugel, P.: Differential response of benthic meiofauna to anoxia with special reference to Foraminifera (Protista: Sarcodina), Mar. Ecol.-Prog. Ser., 158, 151-163, doi:10.3354/meps158151, 1997.

Moodley, L., Schaub, B. E. M., van der Zwaan, G. J., and Herman, P. M. J.: Tolerance of benthic foraminifera (Protista: Sarcodina) to hydrogen sulphide, Mar. Ecol.-Prog. Ser., 169, 77-86, doi:10.3354/meps169077, 1998.

Murray, J. W.: Ecology And Applications of Benthic Foraminifera, Cambridge University Press, 2006.

Murray, J. W. and Bowser, S. S.: Mortality, Protoplasm Decay Rate, and Reliability of Staining Techniques to Recognize "living” Foraminifera: A Review, J. Foraminifer. Res., 30, 66-70, doi:10.2113/0300066, 2000.

Nomaki, H., Heinz, P., Hemleben, C., and Kitazato, H.: Behavior and Response of Deep-Sea Benthic Foraminifera to Freshly Supplied Organic Matter: A Laboratory Feeding Experiment in Microcosm Environments, J. Foraminifer. Res., 35, 103-113, doi:10.2113/35.2.103, 2005.

Nordberg, K., Gustafsson, M., and Krantz, A. L.: Decreasing oxygen concentrations in the Gullmar Fjord, Sweden, as confirmed by benthic foraminifera, and the possible association with NAO, J. Mar. Syst., 23, 303-316, 2000.

Pearson, T. H. and Rosenberg, R.: A comparative study of the effects on the marine environment of wastes from cellulose industries in Scotland and Sweden, Amibo, 5, 77-79, 1976.

Piña-Ochoa, E., Høgslund, S., Geslin, E., Cedhagen, T., Revsbech, N. P., Nielsen, L. P., Schweizer, M., Jorissen, F., Rysgaard, S., and Risgaard-Petersen, N.: Widespread occurrence of nitrate storage and denitrification among Foraminifera and Gromiida, P. Natl. Acad. Sci. USA, 107, 1148-1153, 2010.

Pucci, F., Geslin, E., Barras, C., Morigi, C., Sabbatini, A., Negri, A., and Jorissen, F.: Survival of benthic foraminifera under hypoxic conditions: Results of an experimental study using the CellTracker Green method, Mar. Pollut. Bull., 59, 336-351, 2009.

R Development Core Team: R: A Language and Environment for Statistical Computing, R Foundation for Statistical Computing, Vienna, Austria, available at: http://www.R-project.org/, 2011.

Riedel, B., Zuschin, M., Haselmair, A., and Stachowitsch, M.: Oxygen depletion under glass: Behavioural responses of benthic macrofauna to induced anoxia in the Northern Adriatic, J. Exp. Mar. Biol. Ecol., 367, 17-27, doi:10.1016/j.jembe.2008.08.007, 2008.

Riedel, B., Zuschin, M., and Stachowitsch, M.: Tolerance of benthic macrofauna to hypoxia and anoxia in shallow coastal seas: a realistic scenario, Mar. Ecol.-Prog. Ser., 458, 39-52, doi:10.3354/meps09724, 2012.

Riedel, B., Pados, T., Pretterebner, K., Schiemer, L., Steckbauer, A., Haselmair, A., Zuschin, M., and Stachowitsch, M.: Effect of hypoxia and anoxia on invertebrate behaviour: ecological perspectives from species to community level, Biogeosciences Discuss., 10, 14333-14438, doi:10.5194/bgd-10-14333-2013, 2013.

Risgaard-Petersen, N., Langezaal, A. M., Ingvardsen, S., Schmid, M. C., Jetten, M. S. M., Op Den Camp, H. J. M., Derksen, J. W. M., Piña-Ochoa, E., Eriksson, S. P., Nielsen, L. P., Revsbech, N. P., Cedhagen, T., and Van Der Zwaan, G. J.: Evidence for complete denitrification in a benthic foraminifer, Nature, 443, 93-96, 2006.

Romano, E., Bergamin, L., Ausili, A., Pierfranceschi, G., Maggi, C., Sesta, G., and Gabellini, M.: The impact of the Bagnoli industrial site (Naples, Italy) on sea-bottom environment. Chemical and textural features of sediments and the related response of benthic foraminifera, Mar. Pollut. Bull., 59, 245-256, doi:10.1016/j.marpolbul.2009.09.017, 2009.

Sabbatini, A., Bonatto, S., Gooday, A. J., Morigi, C., Pancotti, I., Pucci, F., and Negri, A.: Modern benthic foraminifers at Northern shallow sites of Adriatic Sea and soft-walled, monothalamous taxa: a brief overview, Micropaleontology, 56, 359-376, 2010.

Sabbatini, A., Bonatto, S., Bianchelli, S., Pusceddu, A., Danovaro, R., and Negri, A.: Foraminiferal assemblages and trophic state in coastal sediments of the Adriatic Sea, J. Mar. Syst., 105-108, 163-174, doi:10.1016/j.jmarsys.2012.07.009, 2012.

Schmiedl, G., de Bovée, F., Buscail, R., Charrière, B., Hemleben, C., Medernach, L., and Picon, P.: Trophic control of benthic foraminiferal abundance and microhabitat in the bathyal Gulf of Lions, western Mediterranean Sea, Mar. Micropaleontol., 40, 167-188, doi:10.1016/S0377-8398(00)00038-4, 2000.

Schumacher, S., Jorissen, F. J., Dissard, D., Larkin, K. E., and Gooday, A. J.: Live (Rose Bengal stained) and dead benthic foraminifera from the oxygen minimum zone of the Pakistan continental margin (Arabian Sea), Mar. Micropaleontol., 62, 4573, doi:10.1016/j.marmicro.2006.07.004, 2007.

Scott, D. B., Medioli, F. S., and Schafer, C. T.: Monitoring in coastal environments using foraminifera and thecamoebian indicators, Cambridge University Press, available at: www.cambridge.org/ 0521561736 (last access: 27 September 2012), 2001.

Semensatto Jr., D. L., Funo, R. H. F., Dias-Brito, D., and Coelho Jr., C.: Foraminiferal ecological zonation along a Brazilian mangrove transect: Diversity, morphotypes and the influence of subaerial exposure time, Rev. Micropaléontol., 52, 67-74, doi:10.1016/j.revmic.2008.06.004, 2009.

Smith, M. S., Firestone, M. K., and Tiedje, J. M.: The Acetylene Inhibition Method for Short-term Measurement of Soil Denitrification and its Evaluation Using Nitrogen-131, Soil Sci. Soc. Am. J., 42, 611, doi:10.2136/sssaj1978.03615995004200040015x, 1978.

Stachowitsch, M.: Mass Mortality in the Gulf of Trieste: The Course of Community Destruction, Mar. Ecol., 5, 243-264, doi:10.1111/j.1439-0485.1984.tb00124.x, 1984.

Stachowitsch, M., Riedel, B., Zuschin, M., and Machan, R.: Oxygen depletion and benthic mortalities: The first in situ experimental approach to documenting an elusive phenomenon, Limnol. Oceanogr.-Methods, 5, 344-352, 2007. 
Tsuchiya, M., Tazume, M., and Kitazato, H.: Molecular characterization of the non-costate morphotypes of buliminid foraminifers based on internal transcribed region of ribosomal DNA (ITS rDNA) sequence data, Mar. Micropaleontol., 69, 212-224, doi:10.1016/j.marmicro.2008.07.008, 2008.

Walton, W. R.: Techniques for recognition of living foraminifera, in: Contributions from the Cushman Foundation for Foraminiferal Research, Scripps Institution of Oceanography, 3, 56-60, 1952.
Wieser, W. and Kanwisher, J.: Ecological and physiological studies on marine nematodes from a small salt marsh near Woods Hole, Massachusetts, Limnol. Oceanogr., 6, 262-270, 1961.

Zwaan, G. J. V. D. and Jorissen, F. J.: Biofacial patterns in riverinduced shelf anoxia, Geol. Soc. Lond. Spec. Publ., 58, 65-82, doi:10.1144/GSL.SP.1991.058.01.05, 1991. 